\title{
Use of Mini-Sprinklers to Strip Trichloroethylene and Tetrachloroethylene from Contaminated Ground Water
}

\author{
Yvette C. Berisford, Parshall B. Bush;* John L. Blakc, and Cassandra L. Bayer
}

\begin{abstract}
Three low-yolume mini-sprinklers were tested for their effeacy to strip trichloroethylene (TCE) and tetrachloroethylene (PCE) from water. Deionized water spiked with TCE and PCE was pumped for approximately $1 \mathrm{~h}$ at 0.19 to $0.21 \mathrm{MPa}\left(28\right.$ to $\left.30 \mathrm{lb}^{-2} \mathrm{in}^{-5}\right)$ through a minisprinkler supported on top of a $1.8-\mathrm{m}$-tall riser. Water was collected in collection vesseis at 0.61 and $1.22 \mathrm{~m}$ above the ground on support columns that were spaced at $0.61-\mathrm{m}$ intervals from the riser base, and samples were composited per beight and distance from the riser. Overall, air-stripping reduced dissolved concentrations of TCE and PCE by 99.1 to 100 and $96.910100 \%$, respectively, from mean influent dissolved concentrations of 466 to $1675 \mathrm{\mu g} \mathrm{L}^{-1}$ TCE and 206 to 940 $\mu \mathrm{g} \mathrm{L}^{-1} \mathrm{PCE}$. In terms of mass removed, the mini-sprinklers removed TCE and PCE at a rate of approximately 1490 to 1700 and 700 to $900 \mu \mathrm{g} \mathrm{L} \mathrm{L}^{-1}$, respectively, over a I-h test period. Mini-sprinkJers offer the advantages of (i) easy setup in series that can be used on practically any terrain; (ii) operation over a long period of time that does not threaten aquifer depletion; (iii) use in small or confined aquifers in which the capacity is too low to support large irrigation or purging systems; and (iv) use in forests in which the small, low-impact droplets of the mini-sprinklets do not damage bark and in which trees can help manage (via evapotranspiration) excess waste water.
\end{abstract}

$\mathrm{T}$ RICHLOROETHYLENE (TCE) and tetrachloroethylene (PCE) are industrial solvents that have been used as cleaning and degreasing agents since the $1930 \mathrm{~s}$ (McCulloch and Midgley, 1996). The USEPA classified both chemicals as "high production volume chemicals," with production exceeding $454000 \mathrm{~kg}$ ( 1 million $\mathrm{lb}$ ) annually in the USA (USEPA, 2000). Because of their widespread use and inappropriate disposal, TCE and PCE are common contaminants in soil and ground water in the USA and are included on at least seven federal regulatory lists (Scorecard, 2001; USEPA, 1998a, 2001: United States Geological Survey, 2001). Some of the present methods used for the remediation of volatile organic chemical compounds (VOCs) from ground water or contaminated soil include phytoremediation (Dietz and Schnoor, 2001; Newman et al., 1997), biodegradation (Leahy and Shreve, 2000; McCarty, 2000; Mihopoulos et al., 2000; van Eckert et al., 2001), in vitro dehalogenation (Chang et al, 2001), dechlorination by metals (Cheng and $\mathrm{Wu}, 2001$ ), chemical oxidation by potassium permanganate (Schnarr et al., 1998; Schroth et al. 2001; Soel and Schwartz, 2000) and hydrogen peroxide (Gates and Siegrist, 1995), pump and treat

YC. Berisford and P.B. Bush, Agricultural and Environmental Services Laboratories, Pesticide and Hazardous Wastes Laboratory, Univ, of Georgia, 2300 College Station Road. Athens, GA 30605. J.1. Blake, U.S. Forest Service, Savannah River Site, P.O. Box 700, New Ellenton. SC 29809, C.L. Bayer, Bechtel Savannah River Inc, Bldg 330-2B. Aiken, SC 29808. Received 6 Feb, 2002. • Corresponding author (pbushoarches.uga.edu)

Published in J. Environ. Oual. 32:80t-815 (2003). technology (USEPA, 1998b), and in situ air-sparging (Adams and Reddy, 1999; Rabideau et al., 1999; Reddy and Adams, 2000; Ryan et al., 2000).

A recent study at the University of Nebraska at Lincoln (Richardson and Sahle-Demessie, 1998) and a follow-up evaluation project by the USEPA SITE Program (in cooperation with USEPA Region 7 and University of Nebraska at Lincoln) at Hastings, NE (USEPA, 1998c) reported that the common agricultural use of sprinkler systems to irrigate crops also reduced the dissolved con. centrations of VOCs in the irrigation water by at least $96 \%$ without a significant effect on air quality. The studies were prompted by a need for alternative, more economical methods to treat ground water. In both studies. the sprinkler system was a pivoting, self-propelled $80-\mathrm{m}$. long boom from which ground water (which was already contaminated with VOCs) was pumped through nozzles along the boom at a rate of $4353 \mathrm{~L} \mathrm{~min}^{-1}(1150 \mathrm{gal}$ $\min ^{-1}$ ). That irrigation system was not used as a remediation method per se. However, since the ground water had been already contaminated with TCE and PCE and since crops are irrigated with boom-type irrigation systems, the investigation centered on remediation as a side benefit of this type of irrigation system. Although that irrigation system could be effective in remediation. its use would be limited to relatively open and flat terrain (slope $<15^{\circ}$ ). A major concern about the use of such large sprinkler systems would also be their effect on aquifer depletion in areas affected by overdraft of ground water resources. This is particularly important in considering that ground water is the basic resource for about $40 \%$ of the public water supply in the USA. and in some states more than $90 \%$ of the water that is used for irrigation is provided by ground water (Cash. 1998: United States Geological Survey, 2000).

The importance of the Nebraska study was that it demonstrated the effectiveness of air stripping by an irrigation sprinkler system. With an emphasis on application to forested land, the present study was conducted to test smaller mini-sprinkler systems that could be set up easily in practically any type of terrain and that could be operated at a substantially smaller risk to ground water depletion. Trees, particularly conifers such as loblolly pine (Pinus taeda L.), would provide a means for managing (via evapotranspiration) the excess wastewa. ter during year-round sprinkler operations. The minisprinklers have small and low-impact droplets that will not damage the bark of trees, which is a problem with typical impact sprinklers that have a concentrated stream and a rotating head. Another advantage of using mini-sprinklers is that many contaminated aquifers are

Abbreviations: PCE, tetrachloroethylene: RPD, relative percent dif ference; TCE, trichloroethylene; VOC, volatile organic compound 


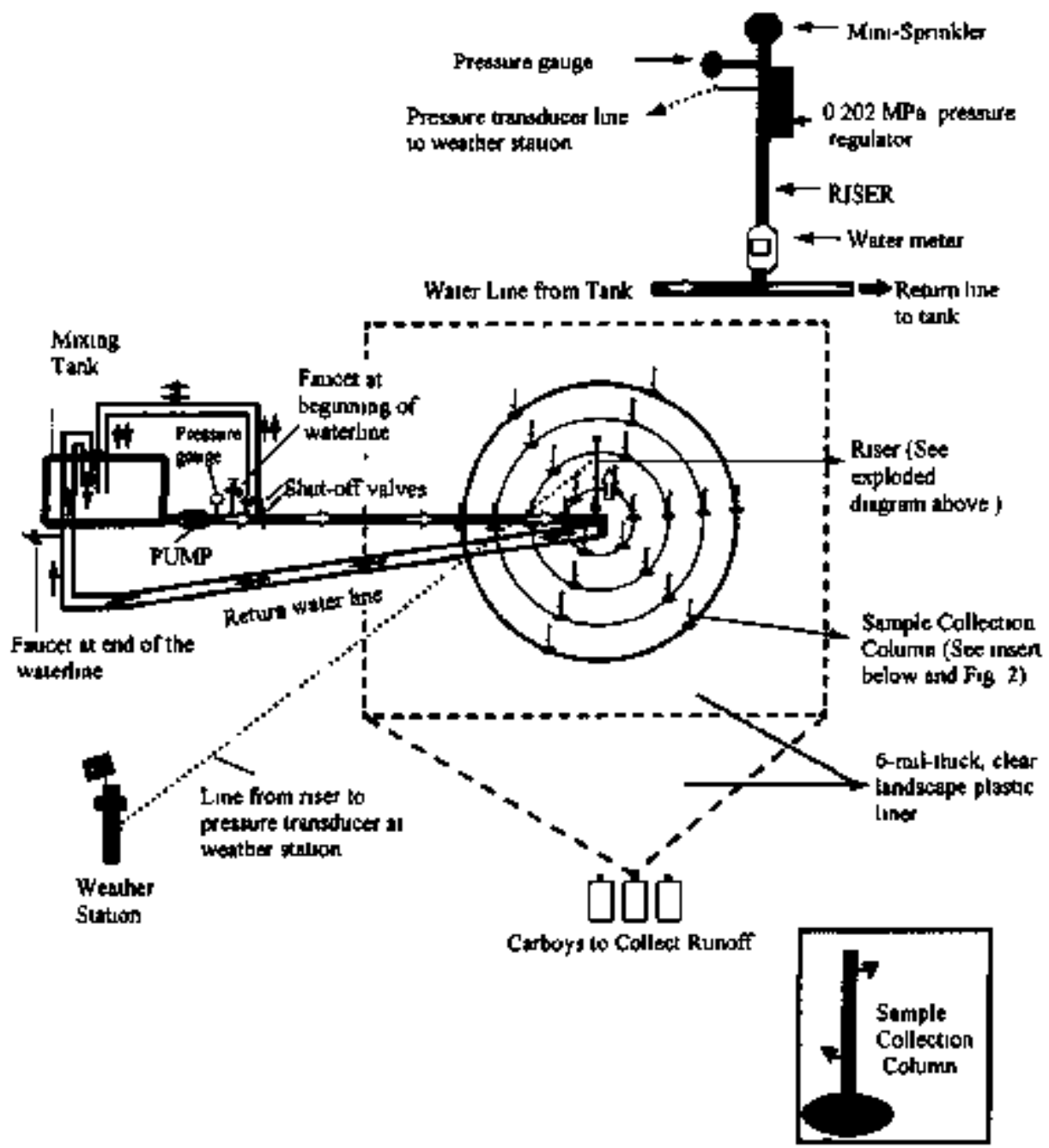

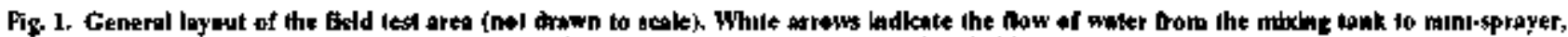

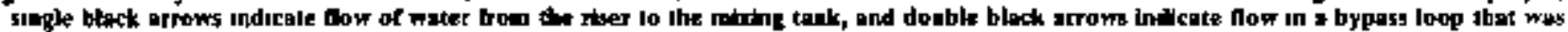

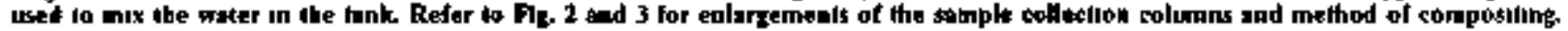

Small or confined and the wells are shallow so that the capacity is relatively low, and bence does not support large urngation systems such as the one used in the Nebraska siudy

Smaller-scaled irrigation systems, such as those that are used on Jawns and un borticulitural greenhouses, can be used on practically any terrain and can be set up within a minimum of cleared land area. Additıonally, such systems could be quickly set up with matertals that arte generally avalable at local gardening and hardware supply oullets, and so offer an additional advantage of quick trobility to address emergency remediation tasks The currenl research tested the efficacy of three types of horticulture mus-sprinkler systems to \$lrip TCE and PCE from contamunated water

\section{MATERJALS AND METHODS Field Design for Eftracy Testing}

The basic desıgn (Fig 1) consisted of a muxing tank from whech desonized water containing TCE (CAS 79.01-6) and
PCE (CAS 127.18.4) was pumped at a pressure of 019 to 021 MPa (28 to $30 \mathrm{lb}^{-t}$ ) through polyethylene เrigation pupe to a mitti-sprinkler that was loceted $18 \mathrm{~m} \mathrm{~h} 1 \mathrm{gh}$ on a riser in the center of a 12 2-m-diameler, cireular area Radiatıng oul trom the base of the nser were four concentnc circles spaced (1) $61 \mathrm{~m}$ apart (Fis 2) Six simple collector columns were evenly spaced on each concenthe arcle so that six rows of four col umns each radiated at approximate $60^{\circ}$ intervals from the base of the mser The entire atea of the columis plus a buffer zone (to catch dntt) was lined with 6-mil-thick clear polyethylene plastse to contain the conlaminated water and collect runoff

The polyethylene isrigation pipe used in this study was selecled because of its general avalabiluty in hardware and Itrigation supply stores throughout the southesstern USA Of concern was the possible adsorption of TCE or PCE to the unside of or lass through the walls of the polyethylene pipe Low-density polyethylene has been used as the membrane is vapor diffusion bag samplers for monilonng VOCs in sedl ment and water withoul any reported significant adsorption to the polyethylese (Vroblesky 2000, 20010,b, Vroblesky and Campbel], 200I) Because of the lack of publeshed data on the behavior (adsorplion to or diffusion through the pipe walls) of TCE or PCE is the type of polyethylene isugutson 


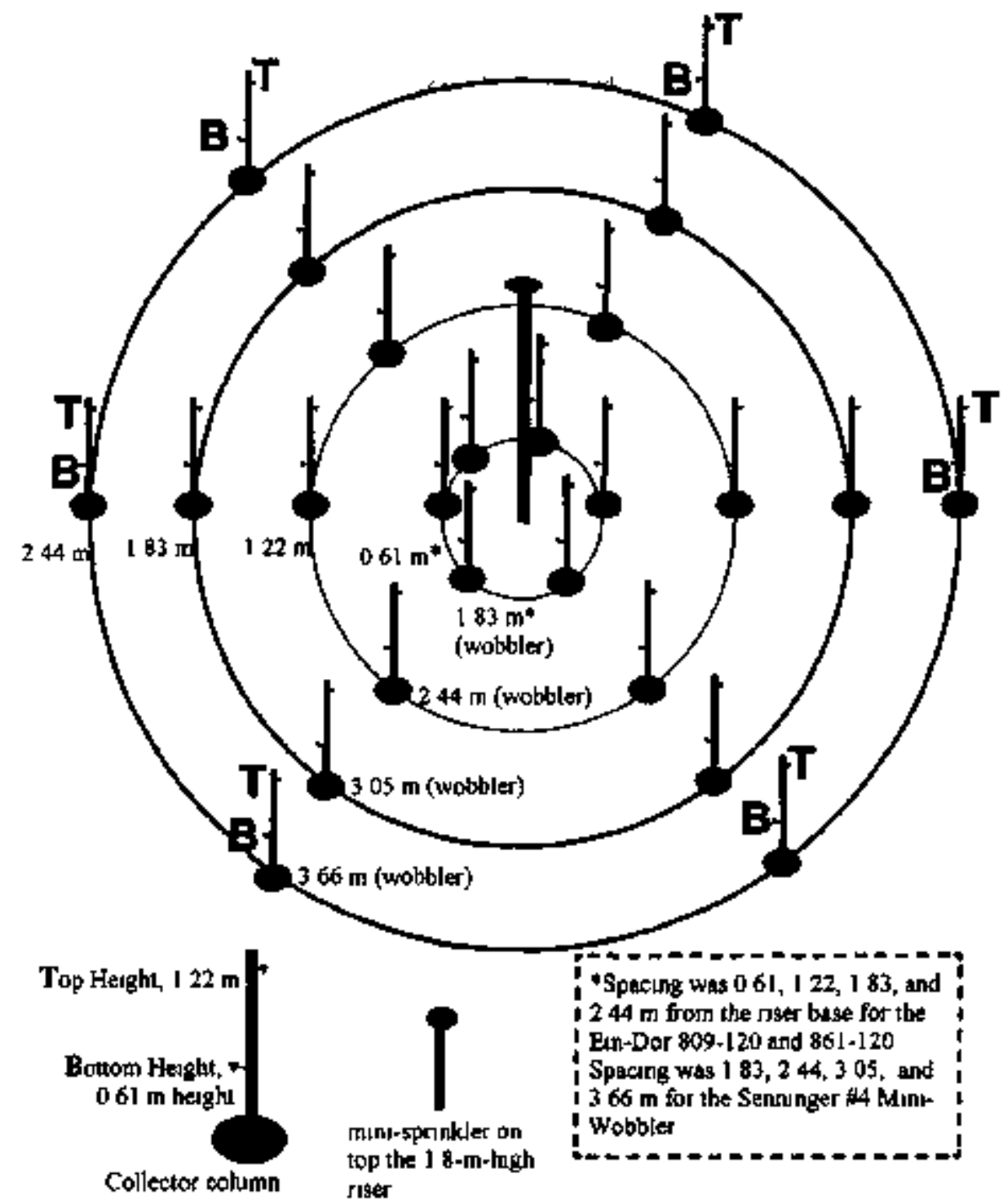

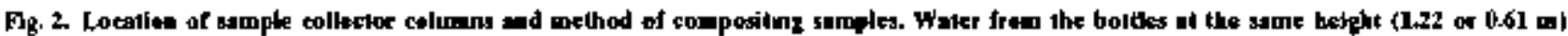

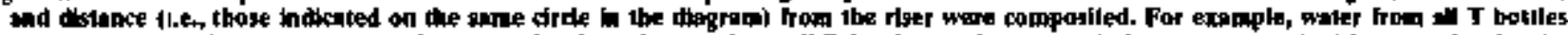

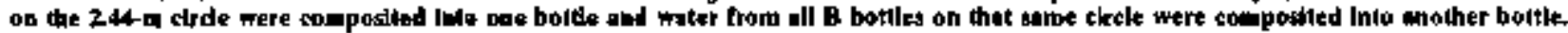

pipe used in our study, the concentrations of TCE and PCE in the pipe al points where the conlaminated water entered and left the pipe were compared ln Fig 1, the potnts of collection are labeled as the laucets at begnming and end of the water line Samples wete collected simulianteously from exach faucet at the beguning, end, and each 15 min of each (est ( $n=5$ per itst) Two tests of each minu-sprinkier system were conducted (total of $\$ x^{x}$ tests) Analysis of variance (SAS PROC ANOVA, $4=0$ OS, Duncan's multiple renge test) was wsed to compare the means of dissolved concentrations of TCE and PCE In the samples collected at the begunning and end of the irtigation pipe for each of the stx tests (SAS Instilute. 2000)

Each collector column (Fıg 3) was made of a $137 . \mathrm{m} \cdot$ long $x$ I $27 . \mathrm{cm}$-duameler (54 in $\times 05$ in) rebas rod inserted into the center of an $X$-shaped base that was constructed from two pieces of $5 . \times 10 . \times 46 \cdot \mathrm{cm}$ (height $\times$ wrdth $\times$ lenglh) untreated Jumber Two collection funnels were clamped to the rod so that the lop of one funnel was $061 \mathrm{~m}$ and the other was $122 \mathrm{rth}$ above the ground A T-L amber glass collectuon boule was clamped beneath each tunnel so that the stem of the furnel extended full length unlo the bottle and the base of the funnel was seated across the openeng of the bottle The funnels were clamped opposite each other so thal they would not obstruct the path of water into each other

\section{Mini-Sprinklet Setup}

Three sprnkler types were tested Sennınger Mını Wobble: ("i4 nozzle, Sefininger lrrigatıon, Orlando, FL) and Eis Dor Model B09-120 and $861-120$ midi-sprinklers (Agridor Ltd Rosh Ha'ayin, Israel) The mint-sprinklers, confectors, pressure regulators, and polyethylene pipe wete supplied by ML lirigation Syslems (Laurens, SC) Some of the thasacteristics of each mini-sprinkler are Istecl in Table I For each test. a mısı-sprinkler was atlached to a $0202 \mathrm{MPa}(20 \mathrm{alm})$ pressure fegulator (Fig 1) mounted on top of a I $27-\mathrm{cm} \cdot 1$ d polyethyt. eue irtigation pupe (see lop ineerl in Fig 1 ) The pupe was 


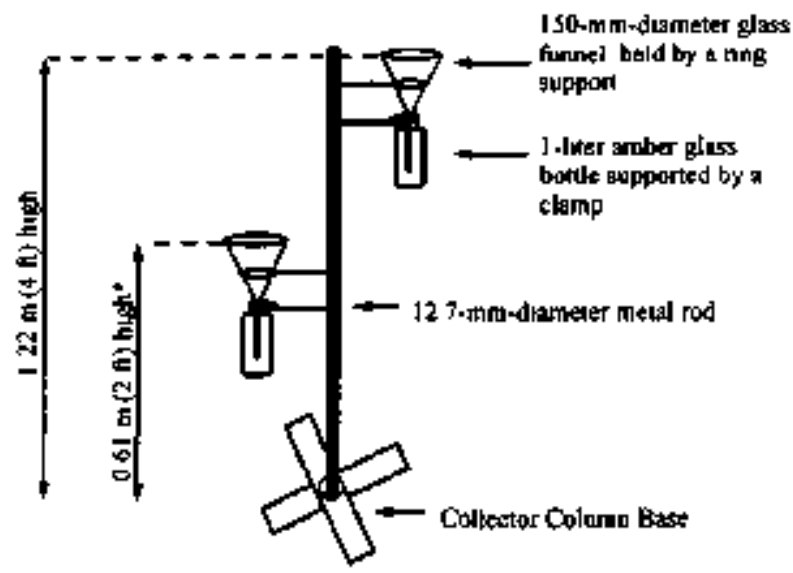

*Height is meassured from the ground to the up of the collection funnel

Flz. 3. Desigh of a sapiple collecllon enteman.

supporled by a me[al support stand ihat held the mini-sprinkler $18 \mathrm{~m}$ atwove the ground The base of the pope al ground level was allached to a water meler that measured the volume of influent water that flowed into the sprinkler A centrifugel pump (Sta Rute 60 Cycle $3 / 4$ hp, Model JHD-62HL, Sta-Rute, Delavan. W'I) pumped water from a 1134 -L-capacity mixıng. tank through an approximate $15 . \mathrm{m}$ long $\times 254 . \mathrm{cm}$. id poly elhylene irsigalion pipe to a $T$-connecior at the base of the water meter Walcit thet did not enler the spinkler returned to the tank through another $15-m$ loop of the irmgation pupe (Flg 1, black arrows) Faucels were allached at the beginning and erd of the water line so thal water could be sampled as It enterred and left the irngation pipe The difference between dissolyed TCE and PCE concertrations in the waler as 14 entered and exuled the pipe would be used 10 rssess the loss of dissolved concentrations of TCE or PCE withın the pipe Waler pressure at the base of the munl-sprinkler was monlcored with a thanually read pressure gauge and a pressure transducer that was copnected to a data logger in a weather station approximately 30 $\mathrm{m}$ from the riser Pressure transducer reibdinys and pressure gauge readings were recorded every 2 and $15 \mathrm{~min}$, respectively, during a lest

\section{Test Conditions}

Test conditions that could not be turtrolled, but whech may alfect the performance of the minl-sprinkler lesl systems, were measured on slle Air temperalure. percent rclative humidily, basome [Tit pressure, solar radiatson, and wind speed and direc. Iron werc recorded every $2 \mathrm{mln}$ by the weather station

Before each test, the mixing tank was rinsed three tImes with approximately $1134 \mathrm{~L}$ of lap water (Alhens. GA clly waler) rolowed by two russes with desonized watcr Each 1] $34 \mathrm{~L}$ aliquot was eqrculated in the lank for approximately l h and then lhe tank was dramed and vacuumed to remove al] standing water from it $\mathrm{On}$ the evenung before a test day. the tank was filled with detonzed water and allowed to vent overnight to remove any free chlonne in the water

On a test day, the water volume in the tank was adjusted to $1134 \mathrm{~L}$ to compensate for overmight evaporation The water was thixed for I h, then $1 \mathrm{~mL}$ each of TCE and PCE in $600 \mathrm{~mL}$ of methanol was added to the tank, and the solution was moxed for an additional $1 \mathrm{~h}$ belore turning on the mini-sprinkler The TCE (stablized, $995+\%$ purily, ACS reagent-grade) and PCE (99+\% purty, ACS reagent-grade) were obtained from J I Baker (Philipsburg, NJ) and Sigma.Aldnch Chemical Company (Milwaukee, WI), respectively

Each minj-spronkler test system was run for approxumaicly I h for each of two tests on the same day The i.h test time was needed so that a suffucient volume of water for a primary. duplicate, and matrix spuke sample could be collected in the boitles on the collection collumns The Senntnger Mon-Wob. bier was tested on $14 \mathrm{Mar} 2001$ from 073 ? to 0852 and 1004 to 1105 h The Ein Dor 809-120 model was tested on 23 Mar 2001 from 0735 to 0838 and 1307 to 1407 h. and the Ein Dor 861.120 model was tesled on 23 Mar $2001 \mathrm{from} 0916101018$ and 1127 to $1227 \mathrm{~h}$

Fiçld blanks of lap water, dejons?ed water, and muxing tank waler (before the addition of $T C E$ and $\mathrm{PCE}$ ) were each placed in 250-mL beakers and exposed to the field conditions in an area near the lest site that precluded exposure to the TCE and PCE solution that was sprayed inlo the als by the minsprınklers

\section{Samplting}

The locations of the sampling statuons and their Irequency of sampling are listed in Table 2 Samples were collected lrom the mixing lank, faucels at the beginning and end of the watcs Ine, colleclors on the colums, beakers on the ground within the test area, runoff, and field blanks. Water from the collector botiles on the columns was composited per height and distance from riser base (Fig 2)

At each sampling 5 la lion, threc semples (primary, duplicate and matrix spike șamples) were collected in prelabeled $60 \cdot \mathrm{mL}$ vials (clear borosilicate glass vals [KımblejKontes, Vunelanu $\mathrm{N}$ J| for USEPA water analys!s) Vials wefe completely tilked to overflowing to elımınate head space betore capping with tellon-lıned lops Each viel contanted $1 \mathrm{~g}$ of phosphate bufter and ammonum chlorsde preseryalive (12 g ammonium chloride lo 2 g dibasic sodium phosphale to 198 g monobasic potassium phosphale) to lower the sample $\mathrm{pH}$ to 48 to 55 and converl tree chlorine to monoch|orame

Samples were placed tn ice chests within 5 min after collectoon Each ice chest conlained tripltrale blanks (three vials each of lap waler, delonized water, and mixing tank water) and a calibraled, digta] thermomeler that mcasured current menuthum, and maximum temperatures Temperatures in the chests were maintained al I to $5^{\circ} \mathrm{C}$ Each sel of field samples was accompaned by a chaln of ctustody form and transferred to a laboratory refngeralor $\left(54^{\circ} \mathrm{C}\right.$ ) within $2 \mathrm{~h}$ after sampling

Table 1. Characteristies of the mind-sprinklers thes were esed In the lesis.

\begin{tabular}{|c|c|c|c|c|}
\hline Miler-sprinkler & Flow rate† & Dropiel sfat & Weltind diametert & Speclal fealure \\
\hline 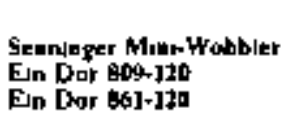 & 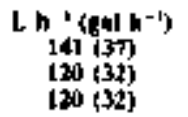 & $\begin{array}{l}\text { medilum } \\
\text { ane } \\
\text { metiluth }\end{array}$ & 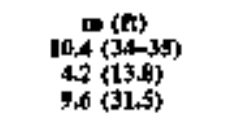 & 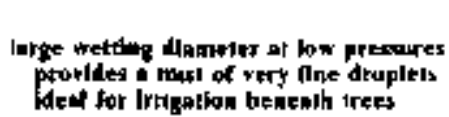 \\
\hline
\end{tabular}

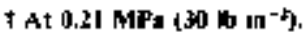

F At 0.21 MPa (30 bo in bi ma a 1.8-m henghi. 
Table 2. Semplipe stotions and frequexcy of sampling.

\begin{tabular}{|c|c|}
\hline Sanplling stauon & Trequoncy and jocoten \\
\hline 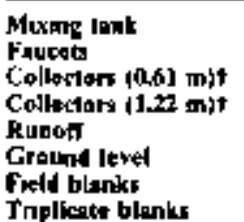 & 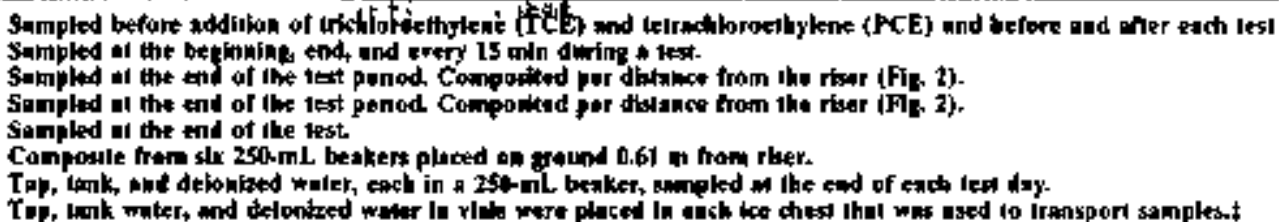 \\
\hline
\end{tabular}

t These are ine boytles an 1he collector colnmen.

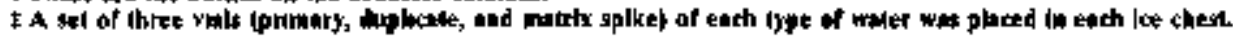

Field Design to Test the Effect of Compositing. and Exposure to Air an Dissolved Concentrations of Tri- and Tetrachloroethylene

Since TCE and PCE are volalle, the physcical process of pouring water from boutes on the collector columns to make a comporte may have resulled in the loss (via volatilization) of dissolyed concentrations of TCE or PCE in the composite Also, dunng the approximale $1 \cdot h$ test of each minu-sprinkler system water in the uncapped collection botiles and groundlevei beakers was exposed to ㅂol, hence, this prolonged exposure during the sample accumulation period could also have caused a loss of dissolved concerilratjons of TCE or PCE in the samples Eıther of these potentjal losses could be mistaken for losses due to stripping by the mini-sprinklers and would result in a greater-than-aclual stnppung efficsenty of the muntsprınkler systems Therefore, an experment was conducted to determine if such losses could ocour under field conditions simalar to those of the mini-sprinkler tests

Three replications, each consistıng of six collector columns thal were evenly spaced in a 122 -m-diametcr circ]c, were set up in the same experimental area where the misl-sprorkler tesils had been conducterd (FIg 4) The same techniques that were used in the mini-sprinkler tests io clean, till, mix, and add TCE and PC.E to the mikitg tank and to collect samples in triplicale were used in this experiment Afler the TCE and PCE had been mixed on the lank for $1 \mathrm{~h}$, the faucet at the begnnung of the waler line was purged for $5 \mathrm{~min}$, and then each of sixty ]-L amber glass boliles was filied with approximalecly $300 \mathrm{~mL}$ of water from this faucet and capped with teflon-lined saps The bottles were randomly allocaled unto five sets of 12 bolthes each Replicalion 1 Replicatıon 2, Replicatıon 3. Time (3 Mıs, and Time 60 Min For Repliestions I through 3 (Fig 4), two boltles were clamped on the collector columns so that the boirles were approximately opposite each other and 122 m high on the column One member of each pair of bottles on exach column was allocated for preparing the composite sample and the of her botte was allocaled for tndividual sampling (roncomposite) The Time 0.Min and Tume 60 Mur botlles were placed on a lab cart near the collector columns Afier all botiles had been clamped on the collector columns, thelr caps were removed The completion of this removal process marked Time 0 or the beganding of the $60 \cdot \mathrm{mun}$ line period A1 this tame. samples were collected from the Time 0 Mın botcles Water from six Time 0 Min bottles was used 10 make threc composiles ( $100 \mathrm{~mL}$ of waler from each bottic), and the othet sıx of the Tume 0 Mun botales were sampled indıvidually Ac the end of 60 mun (from Tume 0), sumilar composites and individual samples were collected from each replicalion and the Time 60 Min bottles

Within each replication and Time 600 Min group, the eficet of composiling on dissolved concentrations of TCE and PCE was analyzed by comparing the mean dissolyed concentration levels in noncomposited $(n-6)$ y composited samples $(n=$ 3) (Fig 5) For sialistical analysis of variance wilhis groups.
SAS PROC GLM ( $\alpha=0$ OS, Duntan's multiple tange test) was used (SAS lnstitute, 2000)

The loss of dissolved concentratıon levels of TCE and PCE during the $60-m i n$ pertod while samples in collectuon bottes were exposed to atr was assessed by comparing mean dissolved concenirations in the noncomposited samples that had been exposed to alr (Replications ], 2, and 3, $n=6$ per replicalıon) with those in the noncomposited samples that had nor been exposed to als (Time 0 Min and Time 60 Min $n=6$ pet group) (Fig 6) Analysis of vortence (SAS PROC ANOVA $a=005$. Duncan's multiple range tesi) was used lo compare the means (SAS Institule, 2000)

\section{Samaple Extraction and Gas Chromatography Anelysis}

All of the primasy samples and $10 \%$ of the duplicates and matnx spuke samples were analyzed A computer progrin; based on Microsofi Excel's random number gencrator (Miscrosolt Corparatıon, 2000), was used to sandomly selecl ithe dupl cale and matr $x$ spike samples for analysıs The relative percent dafference (RPD) for cach sel of held duplicates was calculaled as $100 \times$ (difference between the two values/mean of the iwo values) The RPD should not exceed $25 \%$ for any one anilyte and the RPD for $90 \%$ of the analyles must be less than $20 \%$ (USEPA, 1995) The matrix spıke samples were spiked with $10 \mathrm{~mL}$ of an analytical standard that contalmed Jo ing $\mathrm{L}$ ' ol both TCE and PCE. The percen I recovery in the matrix spikes should falt between 75 and $125 \%$ and the perchal recover|ts of at least $90 \%$ of those 5 prkes must be 80 to $120 \%$ (USEPA 1995) All samples were extracled wilhin their $14 . d$ hutding IImes

The TCE, PCE, decalluorobuphenyl (DFB) atid p bro mofluorobenze ne (BFB) analyucal slandards were oblalnct from AccuStandard (New Haven, CT) Decaluorobiphenyl and p-bromolluorobenzenc were used as the surrogale altd internal standards, respectively Samples were extracted in methyl-ters bulyl ether (MTBE) according to USEPA Mlel bou 5511 (USEPA, 1995), except that Eppendorf pipettes inslead of syrunges were used to add solvents and standards into the vials Two lab spikes (one in deienized and the other in top water) and two lab blanks (delonlzed water and tap water) were extracled and analyzed with each batch of fedd samples Prevjous testing in our lab had detecled a false peak in tap water that could be mistaken for a TCE peak in the lield samples, therefore, since liejd samples could contain residual lap water that was used to clean the mixing lank two sets of extraction batch blanks and spikes, triplicate blanks and field blanks were made fone set from tap water and another set from delonized water)

Extracks were analyzed withun their 14-d holding time on a Tremetres Model 9001 gas chromatograph (Finлigan Corp Austin, TX) equipped with an electron detector and an Rtx I 30-m length $\times 025-\mathrm{mm} \cdot \mathrm{l}$ d Crossbond $100 \%$ dimelhy polyis Joxane column (Restek Corporalıon, Bellefonte PAj The iemperaluse program was first oven temperalure $=40^{\circ} \mathrm{C}$ holk 


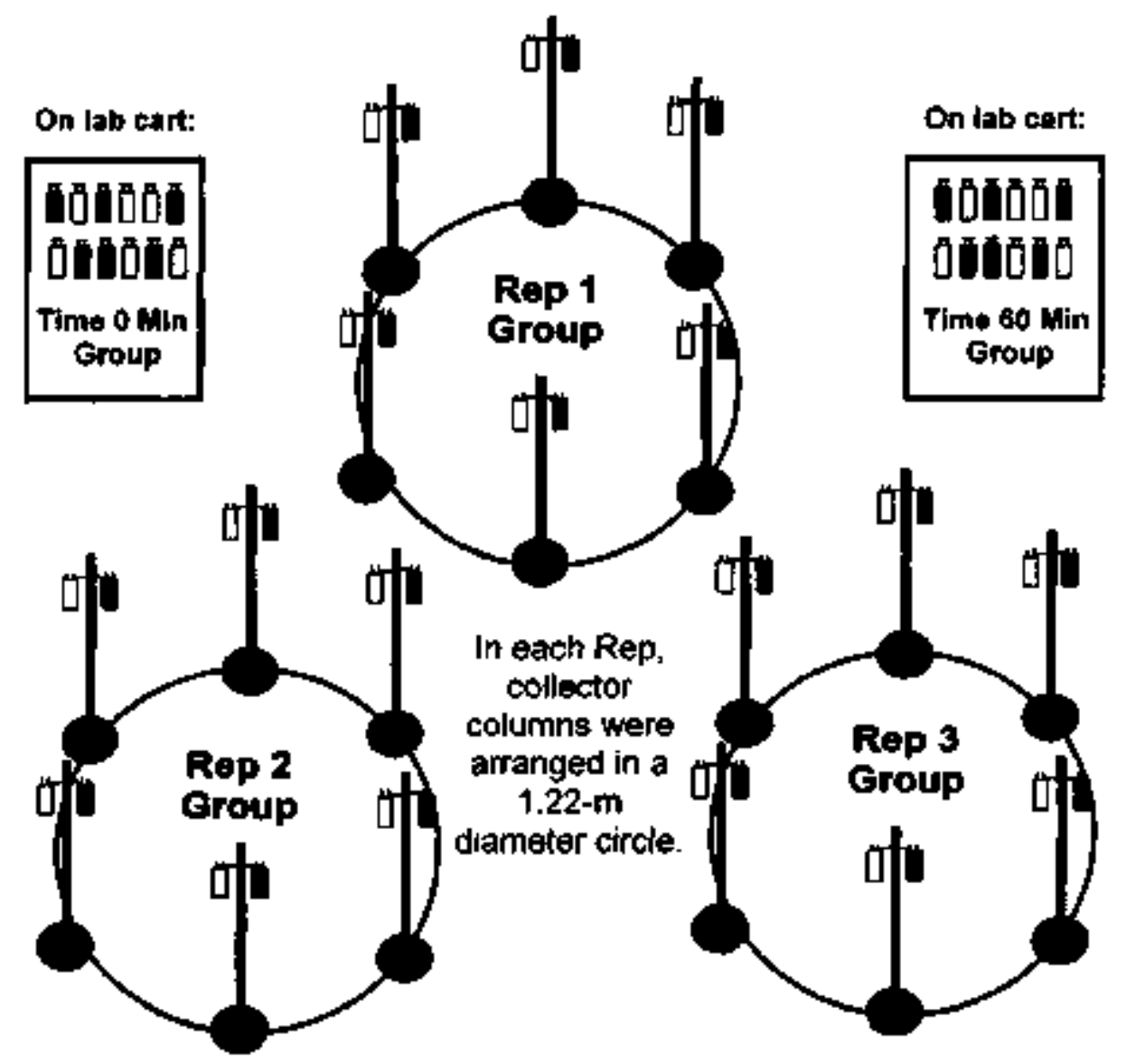

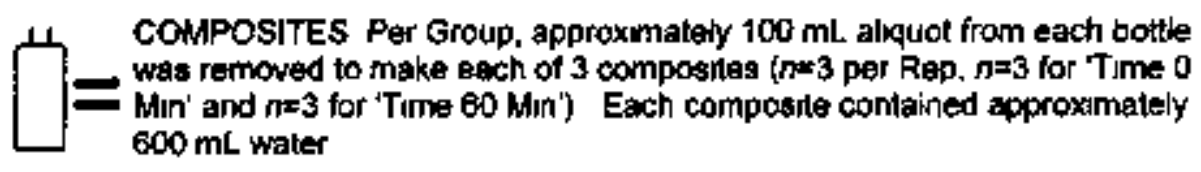
NON-COMPOSITES Bolties from which indridual samples were collecied
within each group at the end of the 60 -minute $(n=6$ per group) last

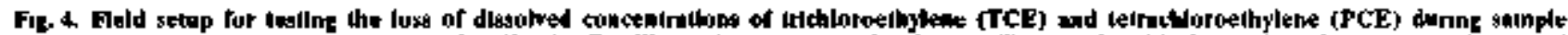

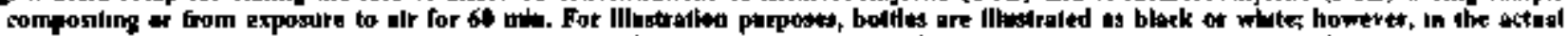

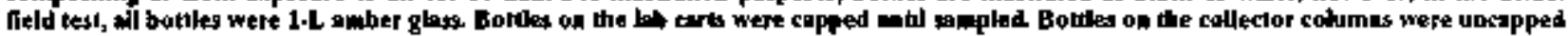
lakaugheat the 60-mis test penod.

7 min, jncrease to $165^{\circ} \mathrm{C}$ at $10^{\circ} \mathrm{min}^{-\mathrm{k}}$, final hold 2 mer Peaks were integraled on a Model 3394A integralor (Hew lett-Packard. Palo A.Jto, CA) Five-point standard calibration curves (001-50 $0 \mathrm{gg} \mathrm{\textrm {L } ^ { - 1 }}$ ) were run for TCE and PCE

Before sumning semples on the ges chromatograph, the following criteria had to be met

] The correlation coefficicnts of tive-point standard curves of TCE and PCE had to be at lisast 099

2 For precision or repeatahlity, the relaluve standard deviatur of three successive injectuons of $2 \mu \mathrm{L}$ of a $01 \mathrm{mg}$ $L^{-1}$ TCE slandard had to be less than $20 \%$ The relative standard dewation was calculated as $100 \times$ (standard devistion of the peak areas of the three injectionsimean of the peak areas of the three נrjeclions)
3 For relative response, the ratio of the peak area of a $2-\mu \mathrm{L}$ in]tecton of a $\mathrm{G}] \mathrm{mg} \mathrm{L}^{-2}$ TCE standerd to the peak

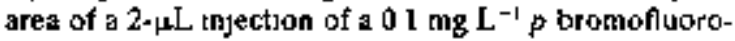
benatne standard hed to agree withn $20 \%$ of the seme relative response of the current standard curve

4 For instrument calibratson varificatıon wilh a midrangc standard, the absolute value of the perctent differente between the instrument's value for a midrange standard contanning TCE. PCE, decafiuorobiphenyl, and $p$.bro mofluorobenzene and its label valut for these com pounds had to be within $15 \%$

5 The instument blank (methy]-ieft butyl ether) could nol contain any peaks of [CE, PCE, decafluotobipheny] or p-bromotluoroberzene 

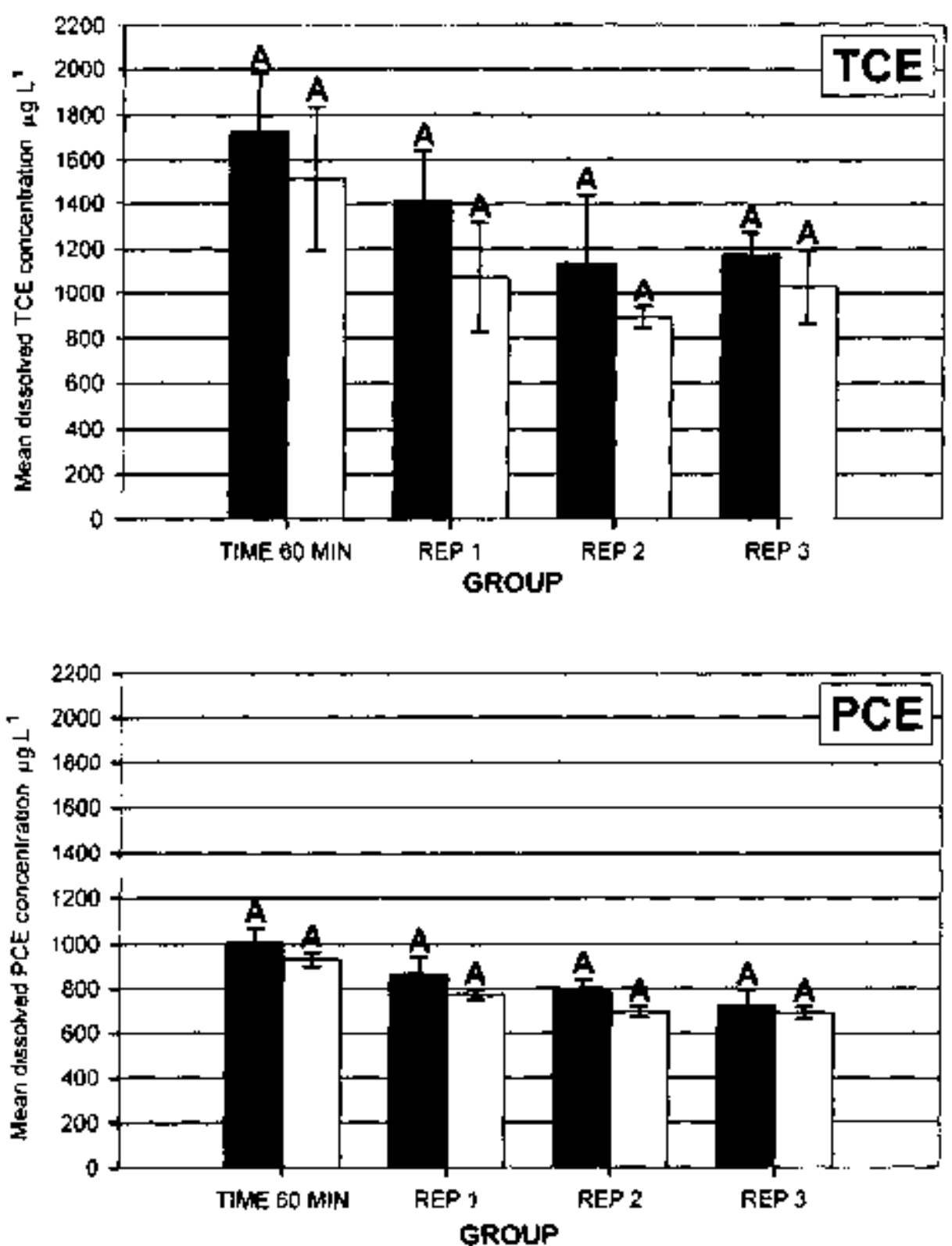

Noncomposited

Composted $I=$ Standard Deviation

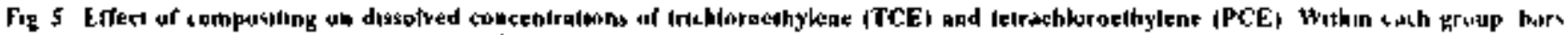

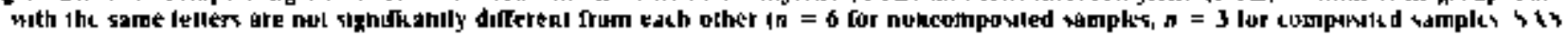
PROC GLM, Duncun's multuple range (est, a - 005 )

The Inethod detcetion limils (MDLj of TCE und PCE in Junn/s ow wer were delermined according to LiSEPA. (1955)

\section{RESULTS AND DISCUSSION}

The standatd curves tor TCE and PCE were liniat Irom toll $105 \mathrm{mg} \mathrm{L}$ ' The MDLs were $229 \mathrm{\mu g} \mathrm{L}$ ' for TCE und 2 ป1 $\mu \mathrm{g} \mathrm{L}^{-1}$ for PCE Dissolved concedutitions bolow the MDLs die reported as nondeteclable The

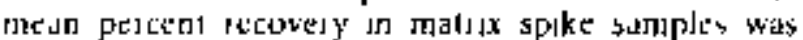
$1115 \pm 12 \mathrm{k} \%(n=12)$ lor TCE and $963 \pm 102 \%$

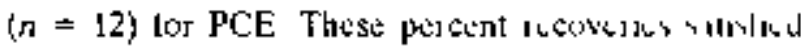

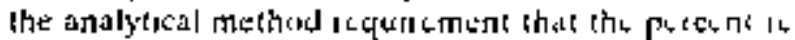

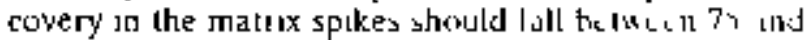

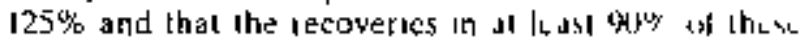
sp]kes must be 8 il to [20\% (USEPA 145) The ILlallat

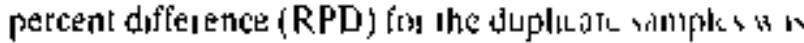
less than $20 \%$ in $918 \%$ ot the dupluals los henll It l (range of $00-160 \% n=12$ ) and PCE (t ill on in) th

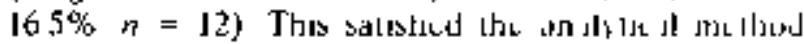

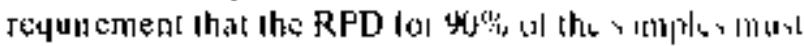



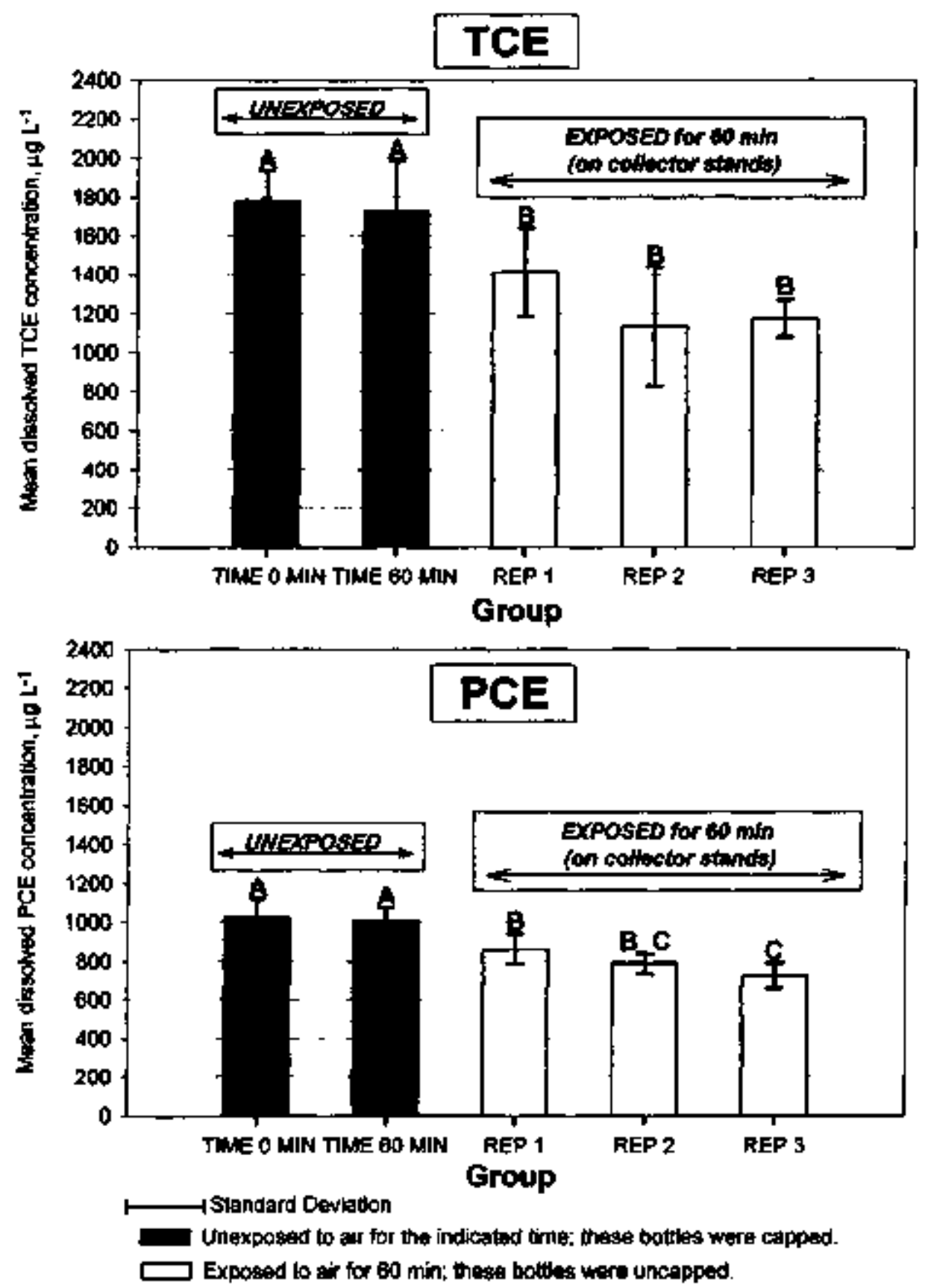

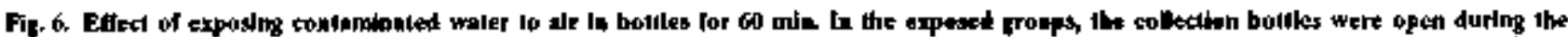

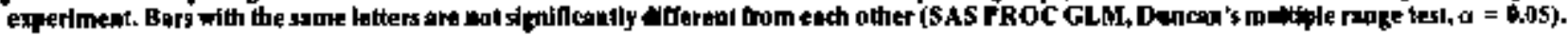

nol exceed $25 \%$ for any analyte \{USEPA, 1995 ). The RPD exceeded $20 \%$ in one duplicate sel for both TCE $(\mathrm{RPD}=31.5 \%)$ and PCE $(\mathrm{RPD}=34.3 \%)$. The mean percent recovery of the surrogate (decafluorobiphenyl) for the sludy was $66.7 \pm 10.8 \%(n=209)$.

Compositing did not have a statisticaliy significant effecl on the dissolved conceatration levels of TCE or PCE (Fig. 5); however, statistically significant losses were incutred during the lag time of approximately $1 \mathrm{~h}$ during which contaminated water was exposed to air inside the collection boltles (Fig. 6). Overall, the mean dissolved TCE concentrations were $28.2 \%$ lowes in the exposed water than in the unexposed water. Similarly. mean PCE concentrations were $21.2 \%$ lower in the exposed water. The overall percent loss was calculated as the percent difference belween mean dissolved concen. trations in the water from bottles that had heen unexposed to air for $60 \mathrm{~min}$ (Unexposed, Time $60 \mathrm{Min}$ grüup, $n=6 ;$ Fig. 6) and the mean dissolved concentrations in water that had been exposed in bottles for 60 min (Exposed, Replications 1-3, $n=18$; Fig. 6). The mean dissolved concentrations of TCE in exposed vs. unex- 


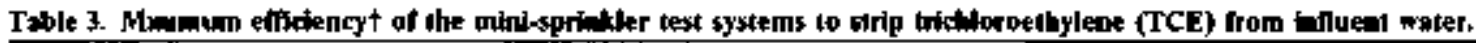

\begin{tabular}{|c|c|c|c|c|c|c|}
\hline Mint-spнabler & Terl & $\begin{array}{l}\text { Inftietil } \\
\text { sontentraliont }\end{array}$ & $\begin{array}{l}\text { Highes concentrition } \\
\text { in collattort }\end{array}$ & $\begin{array}{c}\text { Lost in } \\
\text { eollecierst }\end{array}$ & 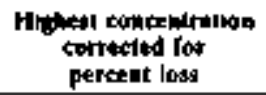 & 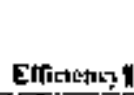 \\
\hline & & & L' & $\%$ & $\mu_{E} \mathbf{L}^{\prime}$ & ${ }_{4 i j}$ \\
\hline $\begin{array}{l}\text { Senninger Muni-Wobbler } \\
\text { Semninger Mini-Wobbler } \\
\text { Ein Dor } 109-170 \\
\text { Ein Dor B09-120 } \\
\text { Ein Dor } B 65-120 \\
\text { Ein Dor B6t-120 }\end{array}$ & $\begin{array}{l}1 \\
2 \\
3 \\
2 \\
2 \\
2\end{array}$ & $\begin{aligned} 1673 & \pm 251 \\
728 & \pm 84 \\
1502 & \pm 119 \\
466 & \pm 34 \\
1392 & \pm 297 \\
630 & \pm 171\end{aligned}$ & $\begin{array}{l}7.2 \\
0.0 \\
9.5 \\
0.0 \\
2.7 \\
0.0\end{array}$ & $\begin{array}{l}2,1 \\
20.2 \\
20.1 \\
28.2 \\
20.2 \\
28.2\end{array}$ & $\begin{array}{r}10.0 \\
10 \\
13.2 \\
40 \\
3.8 \\
00\end{array}$ & $\begin{array}{r}99 d \\
11040 \\
991 \\
1004 \\
907 \\
1000\end{array}$ \\
\hline
\end{tabular}

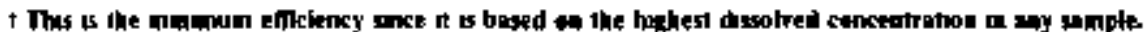

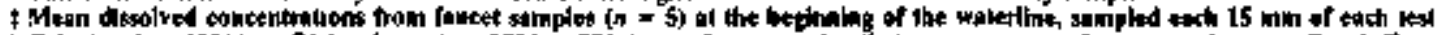

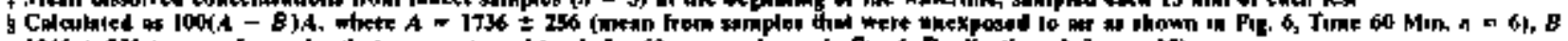

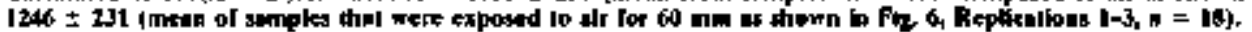

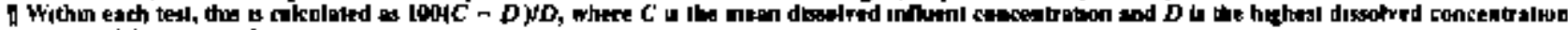
rottected tar percent lase.

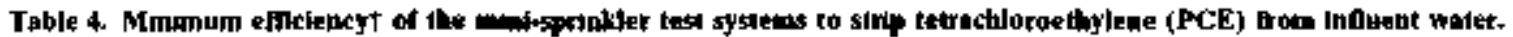

\begin{tabular}{|c|c|c|c|c|c|c|}
\hline SinI-sprmikker & Tex & $\begin{array}{c}\text { Innowent } \\
\text { concenirmalunt }\end{array}$ & 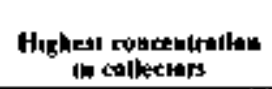 & $\begin{array}{l}\text { Low in } \\
\text { apllecturyt }\end{array}$ & 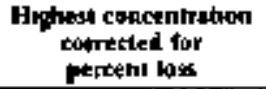 & 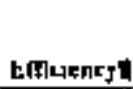 \\
\hline & & & $L^{\prime}$ & 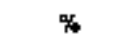 & $\mu_{g} L^{\prime}$ & $\%$ \\
\hline 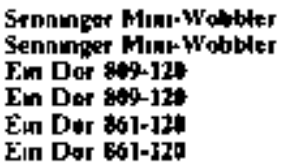 & $\begin{array}{l}1 \\
2 \\
\mathbf{1} \\
2 \\
\mathbf{1} \\
\mathbf{2}\end{array}$ & $\begin{array}{l}94 \pm 134 \\
45 \pm 84 \\
766 \pm 56 \\
206 \pm 31 \\
734 \pm 76 \\
401 \pm 74\end{array}$ & $\begin{array}{r}4,3 \\
00 \\
16,6 \\
0.0 \\
0.0 \\
10\end{array}$ & $\begin{array}{l}21.2 \\
21.2 \\
21.2 \\
21.2 \\
21.2 \\
21.3\end{array}$ & $\begin{array}{r}5.5 \\
0.0 \\
23.6 \\
0.0 \\
00 \\
0.0\end{array}$ & $\begin{array}{r}994 \\
1000 \\
969 \\
1000 \\
1000 \\
1000\end{array}$ \\
\hline
\end{tabular}

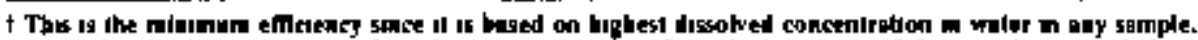

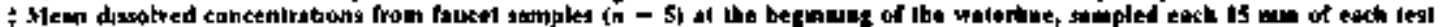

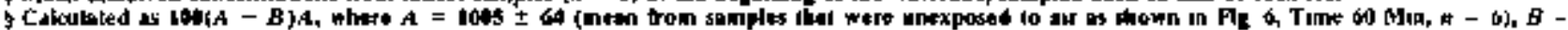

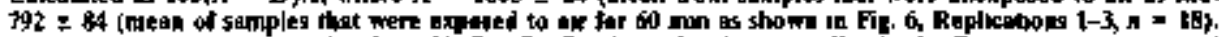

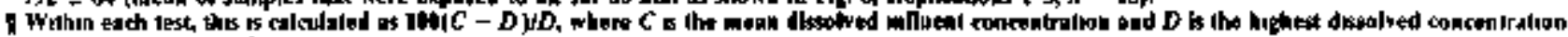
cortected for pertent lass

posed water were $1246 \pm 231 \mu \mathrm{g} \mathrm{L} \mathrm{L}^{-1}$ vs $1736 \pm 256 \mu \mathrm{g}$ $\mathrm{L}^{-1}$, respectively For $\mathrm{PCE}_{1}$ the values were $792 \pm 84$ $\mu \mathrm{L}$ ' vs $1005 \pm 64 \mu \mathrm{g} \mathrm{L^{-1 }}$, respectivedy, in exposed vs unexposed water

The efficiency of each mol-sprinkler test system was calculaled in Tables 3 and 4 Efficency refers to percent of TCE or PCE that each syslem stnpped from the Influent water The efficiencies lake unto account the estimated loss of TCE and PCE during the 1-h exposure of water in sample collection bottles as explained in the prevous paragraph Dissolved concentratuons of TCE and PCE were not delected in the second test of each mun-sprinkler system (Tables 3 and 4) In the first tests, the Senninger Min-Wobblet system was efficient in teducing dissolved concentrations of both TCE and PCE by $994 \%$ Simularly, the EIn Dor $809-120$ was $991 \%$ (TCE) and 969\% (PCE) efficsenl The Ein Dor 861 120 reduced TCE concentralions by $997 \%$ and PCE was not delected in any sample collector th that system Elficiencles were $100 \%$ for the 1ests in which TCE or PCE wcre not detected In these cases, effuelency seems to be $100 \%$, however, that may be a reflection of the lower dissolved concentrations of TCE and PCE in the unfluent water for these tests (T) vs T2 in Fig 7 and 8) Aa important factor to constder about the lack of detectable TCE or PCE in the second tests is that the injtal dissolved concentrations in the influent waler in the second tests were 45 to $74 \%$ less than those in the (irst cests (T1 vs $T 2$ in Tables 3 and 4 ), hence the total dissolved mass of TCE or PCE in each second test may have been below the strupping capacity of thal test sys- tem (Table 5) Table 5 shows the tota] dissolved mass of TCE and PCE un the influent water volume that was subject to stnpping durug each approxumate 1 h icst If the total dissolved mass of TCE and PCE in each first test were to represent the siripping capacity of that test system, then there was insufficient dissolved mass in the second test of any system to challenge that capacity Hence, neither TCE nor PCE should be detected th the sceond lests as was the case un this study For cxample If the dissolved mass of TCE in the first Senninger Mis Wobbler lest were reduced by $994 \%$ (ftom iatle 3) then that system had the capacily to remove a total mass of $287037 \mu g$ of TCE The total drssolved mass renoted was calculated as (strupping efficiency from Table 3) $x$ (TCE thass in the influent water volume from Table $\overline{\text { j) }}$ In the second test of that same system, only B2 $555 \mu$ g, was present in the influent water volume (Tabte 5) Thus amoun was below the $287037 \mathrm{\mu g}$ strippeng capaclyy of the system and therefore $100 \%$ slxipping (above the method detection lamit of $229 \mathrm{\mu g} \mathrm{^{-1 }}$ ) of the TCE would be expected

The reduction in the unttal dissolved concentrattons of TCE and PCE in the influent water in the second lests of each mmn-sprinkler system were mosi probably due to volatilization in the mixing tank, and not to any significant loss in the polyethylene imgation pupe Three faclors that support this probability ate (1) the spiket water in the mixing lank was nol replaced before the second test of any muni-sptunkler syslem, (t) the lank contanned a large headspace that would have aliowed for volatilization loss between tests, and (In) there was 


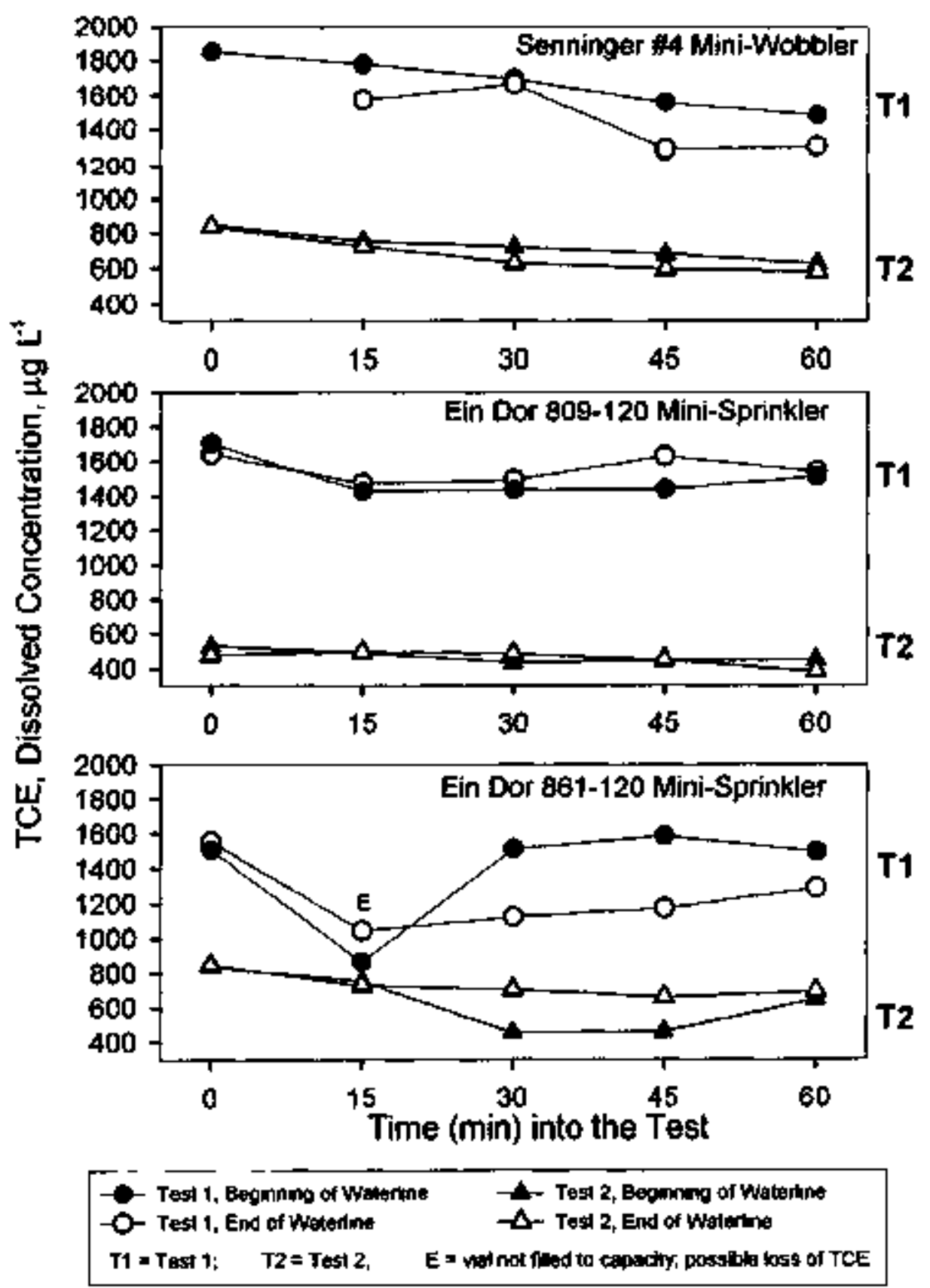

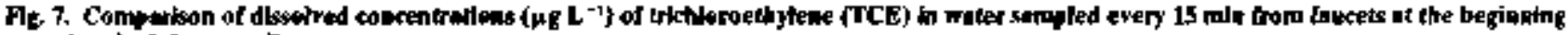
and end of the wastertie.

no significant loss in dissolved concentralions in the walerline (Fig. 7-9).

Anolher factor to consider in the lack of detectable

TCE or PCE in the second lests of each mini-sprinicler system is that as a lest day progressed from early morning through early afternoon (refer to Table 6 for test dales and times), meteorological conditions changed to enhance volaulization, evaporation, and drift. Temperature, wand speed, and solar radjatzon increased and percent relative humidity generally decreased dunng the day For the tests tha! began before $1000 \mathrm{~h}$, the tempera. ture, solas radiation, wind speed, and pertent relalive hurnidity ranged from 6.7 to $13.9^{\circ} \mathrm{C}, 180$ to $850 \mathrm{~W} \mathrm{~m}^{2}$, 0 to $11.26 \mathrm{~km} \mathrm{~h}^{-1}$ (0 to $7 \mathrm{mu} \mathrm{h}^{-1}$ ), and 49 to $79 \%$, respectively, compared with 15,0 to $194^{\circ} \mathrm{C}, 400$ to 1 it) $W \mathrm{~m}^{2}, 1.61$ to $14.48 \mathrm{~km} \mathrm{~h}^{-1}$ ( 1 to $9 \mathrm{mu} \mathrm{h}^{-1}$ ), and 29 10 $47 \%$ for the tests that began after $1000 \mathrm{~h}$

Meteorological conditions cannot be controlled, but may have a significant effect on the stripping efficlency of the mini-spnnkJers. The effects of meteorological conditions on the observed strupping effrcencles would be greates1 at elevated temperatures, wind speeds, solat radiation, and lower relative percent humuduty To test this 3n our study, the Ein Dor 809-120 sprinkJer system 


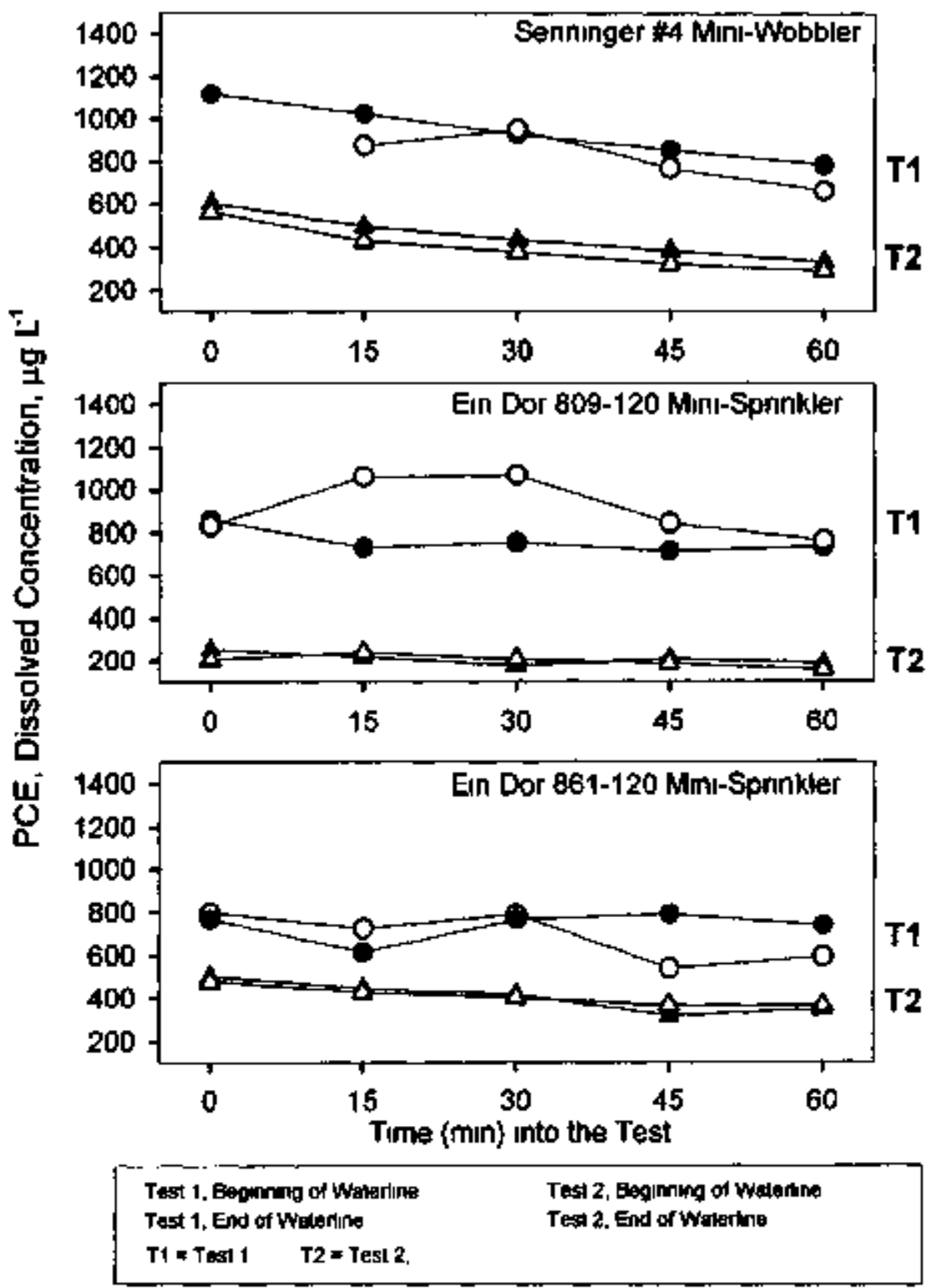

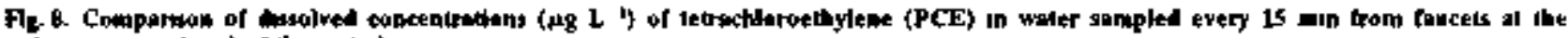
beginang and exd of the walerline.

was tested dunng the mornung (0735-0838 h) and afternoon (1307-1407 h) (Table 6) The test times were chosen to depict a relat\}ve "worst-case scenario" for volstilization of the VOCs during early morning hours and a better-case scenarion later in the afternoon when as temperaluses, wad speed, and solar radialion were higher and peteent relative humidjty was lower The best case scenario" would have been mid to late-afier. noon hours, however, all tests were conducted during conditions that manumized drift from the tes! sile As seen in Table 6, the percent sunoff volume for the Eur Dor 809120 moning test was approxıлately twice (55 vs $2 B \%$ ) that of its aftemoon test, and the persent unaccounted water volume was approximately $20 \%$ less (42 is $69 \%$ ) in the moming test The mosl obyous factors that accounted for these differences would in clude loss of runoff volume due to drift and evaporation The Ejn Dor \$09-120 produced a visıbly very fine nissl that was abserved to dnft offsite, the other minu sprin klers did not produce such a mis! Drift (which may contau other undesirable contammants) to sensilsve offsite areas would be a major factor to constder $t \Omega$ using rurns-sprinklers and may regulate the operaling conditıons ander which the sprinkler sysiems could be 


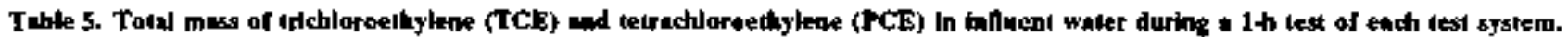

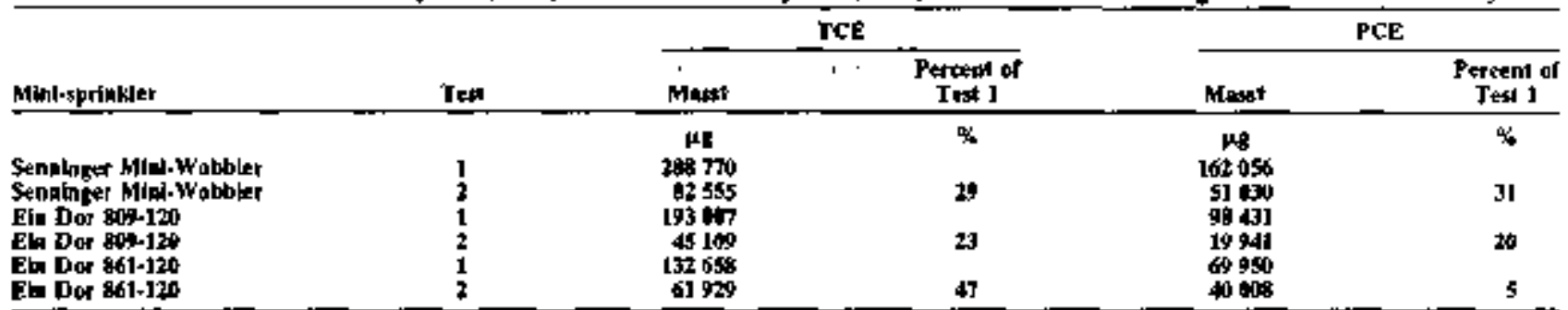

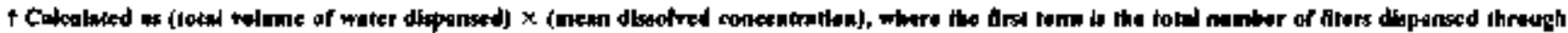

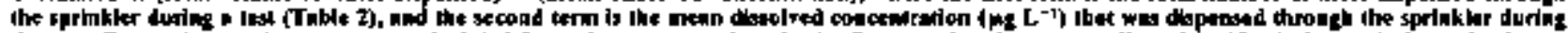

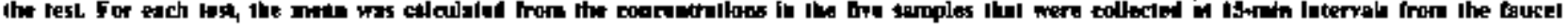

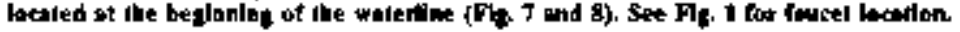
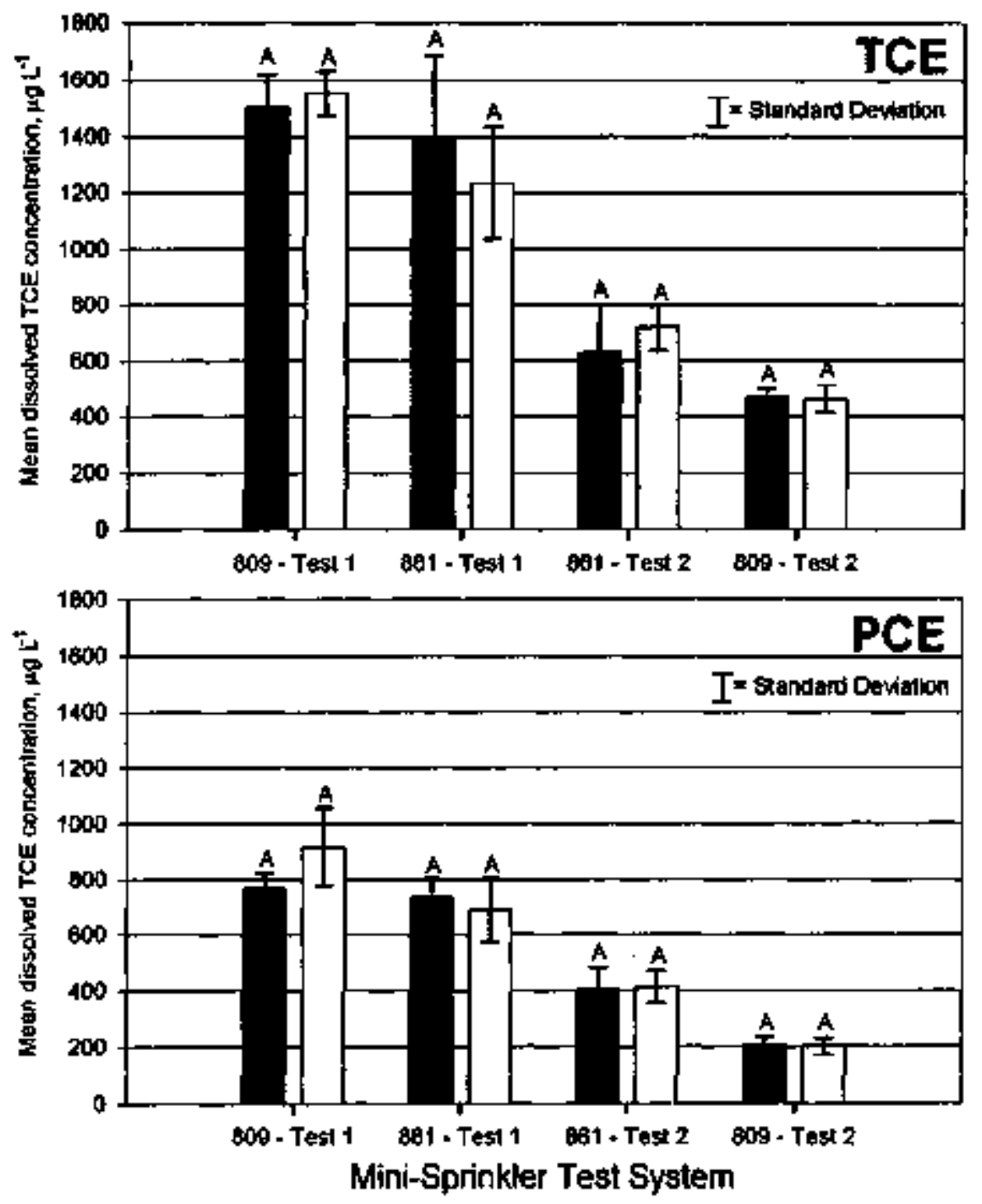

Residues in water from faucet at the beginning of the walerline Residues in water from fauced at the end of the waterline

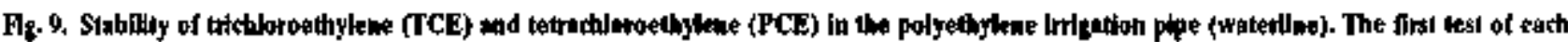

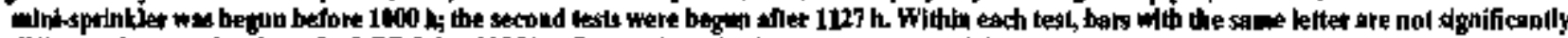

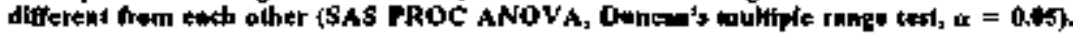




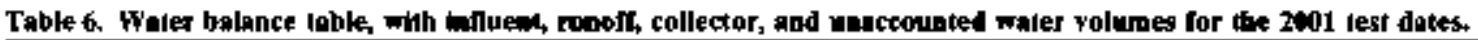

\begin{tabular}{|c|c|c|c|c|c|c|c|}
\hline Minı-sprinklet & Teil & Teيl dalt & Terl inte & Laflocent & Runot & Collectorta & Unocrounled' \\
\hline & & & h & 311 & $L(x)$ of & I water qoluen & \\
\hline 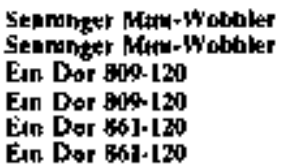 & $\begin{array}{l}\text { I } \\
\mathbf{1} \\
2 \\
1 \\
2\end{array}$ & 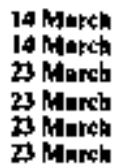 & 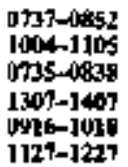 & $\begin{array}{l}174 \\
1134 \\
1285 \\
968 \\
953 \\
943\end{array}$ & $\begin{array}{l}1123(65) \\
74 t(65) \\
703(55) \\
26.8(28) \\
74.1(75) \\
76.4(38)\end{array}$ & $\begin{array}{l}1.7 \text { (1) } \\
1.0 \text { (1) } \\
4.7 \text { (4) } \\
3.1 \text { (3) } \\
1.5(2) \\
1.6(2)\end{array}$ & $\begin{array}{l}56.2(34) \\
38.2(34) \\
53.7(42) \\
60.9(69) 1 \\
197(21) \\
20.4(71)\end{array}$ \\
\hline
\end{tabular}

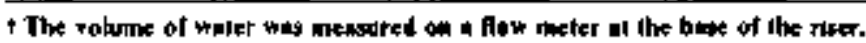

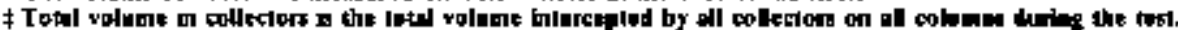

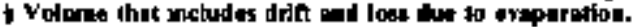

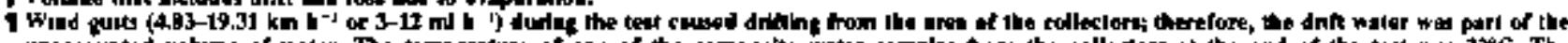

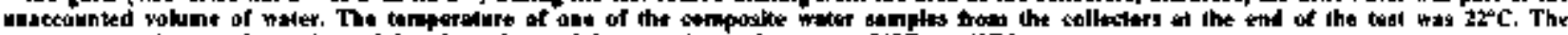

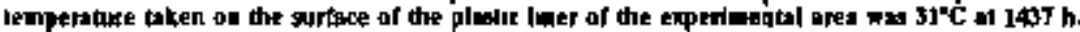

operaled Although much druftung of the water from lhe Ein Dor 809-120 syslem was observed, a downward direction of the drift pattern was also visible This downward drifting resulted an nearly two to five lumes as much water volume in the sample collectors for this syslem as compared with the En Dor 861-120 and Senninger Mini-Wobbler systems (Table 6) For the Ein Dor 861-120 and Senminger Min1-Wobbler systems, there were only shght differences (Wizhon each system) in the percent of runoff wates volume or percenl volume of water in collectors or percen1 unaccounted water yolume between tesis un the early or late moming hours (Table 6, values in parentheses) The slight differences as opposed to the major differences for the Ein Dor $809-120$ lests were probably due to a combunalion of droplet stzes emitled by lhe mint-spnnklers and the much more divergent meteorological condrtions be. tween the Ein Dor 809.120 morning and afiemoon tests

We detected TCE and PCE in 12 of the 62 samples collected from water lhat flowed through the mun.sprin. kJers Of these $12,8(n=24)$ were from the 122 -mhigh collectors, ] $(n=24)$ from a $061-m-h i g h$ collector, 2 from beakers on the ground ( $n=6$ ), and 1 from nuoff $(n=8)$ The dissolved concentrations of TCE were significantly higher in the $122 \cdot \mathrm{m}$-bigh collectors (mean $=2892 \neq 3292 \mu \mathrm{g} \mathrm{L}^{-1}, n=24$ ) than un the 061 $m$ high collectors (mcan $=0275 \pm 0953 \mu \mathrm{L} \mathrm{L}^{-1}, n=24$ ) (SAS PROC ANOVA, $\alpha=0$ 05), but not signitwantly different al different distances from the base of the nser (SAS PROC GLM, $a=005$ ) Among the three minisprunklet systems, mean dissolved concentrations of TCE were signdicantly higher in the Ein Dor \$09-120 sysiem (mean $=3175 \pm 4104$ ) than in the Eun Dor
$861-120$ syslet $($ mean $=0338 \pm 0955$ ), but there were no significant differences in the dissolved concenluations between the Senninger Muni-Wobbler system (mean = $1237 \pm 1331 \mu \mathrm{g} \mathrm{L}^{-1}$ ) and either of the other two minlspnnkier systems Mean dissolyed concentralıons of PCE were not significandy different among the min!sprinkler systems, distances from the base of the riser. or between the $06 \mathrm{l}$ - and $122-\mathrm{m}$ heights on the collec tor columins

The masses of TCE and PCE removed from the inlluent water for each minı-sprinkler and the agricultural boom-type rrigation spnnkler used in the Nebraska study (Richerdson and Sahje-Demesse, 1998, USEPA. 1998c) are compared un Tables ? (for TCE) and 8 (for PCE) In tems of total mass rcmoved (Column $D$ in the tables), the latger boom-1ype spnnkler removed 590 to 1044 tumes mote TCE and 14 to 28 times more PCE as did the mun-sprunkjers However, the total influen! volume un the boom type spnnkler was 1894 to 2832 times grealer than that of the mut-spriaklers and the Intial dissolved concentrations of TCE and PCE were approximately 5 and 100 times less, respectuvely, than those for the mini-sprnkler tests This made comparsson of the two types of irrgation systerns unequal For a more equttable companson, the mean influent conceл. tration of the boom-type system was "adjusted" to re flect that of the munt-spruklers by setting the mean ufluent concentration of the mun-sprinklers (irom Col umn $A$ th the Tables 7 and $B$ ) as the mean intlutenl concentration for the boom-lype sprinklet These ad justed yalues are shown in parentheses in Tables 7 and 8 With the adjusted concentralion value. the boom type spinkler still removed more mass of TCE and PCE

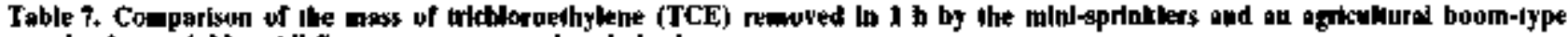
oripatioe spinkles. All figures are on a per hondy bast.

\begin{tabular}{|c|c|c|c|c|c|}
\hline Test system & 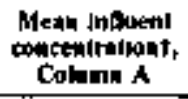 & $\begin{array}{c}\text { Influcal maler } \\
\text { valunite } \\
\text { Coluinin B }\end{array}$ & $\begin{array}{l}\text { TCE mass in } \\
\text { miluent waltsta } \\
\text { Collum C }\end{array}$ & $\begin{array}{l}\text { TCE mota } \\
\text { strppotst. } \\
\text { Collume D }\end{array}$ & $\begin{array}{l}\text { TCE mass strupped } \\
\text { per } L \text { InthuenI waler } 1 \text {. } \\
\text { Column } E\end{array}$ \\
\hline & HE $1^{-1}$ & $\mathbf{L}$ & 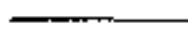 & $-\infty$ & pel' \\
\hline 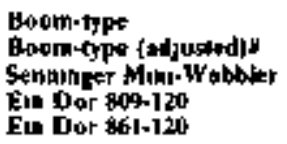 & $\begin{array}{c}530=266 \\
11529) \\
1675 \pm 151 \\
1503=118 \\
1392=197\end{array}$ & $\begin{array}{l}261165 \\
261164 \\
117.9 \\
272.4 \\
92.2\end{array}$ & $\begin{array}{c}139 \times 10^{4} \\
\left.139610^{4}\right) \\
210983 \\
103 \approx 45 \\
117891\end{array}$ & $\begin{array}{c}136 \times 70^{4} \\
{\left[390 \times 10^{4}\right)} \\
139597 \\
107190 \\
127497\end{array}$ & $\begin{array}{l}519 \\
\text { (1 } 493) \\
1665 \\
1458 \\
1383\end{array}$ \\
\hline
\end{tabular}

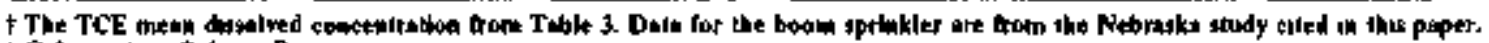

$\neq$ Column A $\times$ Colano B.

$\$$ Codnmn C X \% permoral.

1 Celamn DiColumn B.

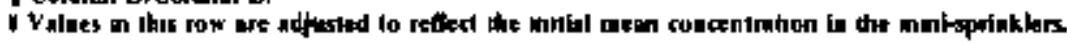




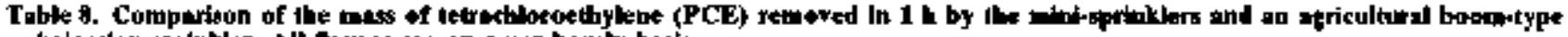

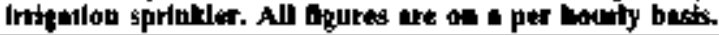

\begin{tabular}{|c|c|c|c|c|c|}
\hline Test sysicm & $\begin{array}{l}\text { Mene Infiednt } \\
\text { cobcunirellont, } \\
\text { Colunin } A\end{array}$ & $\begin{array}{c}\text { Iniluenl waler } \\
\text { volumits, } \\
\text { columin } \mathbf{B}\end{array}$ & 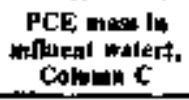 & $\begin{array}{l}\text { PCE nans } \\
\text { Ihpped } \\
\text { Colomoh } 0\end{array}$ & 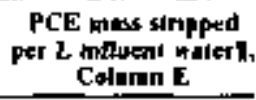 \\
\hline & $\boldsymbol{\mu} \mathbf{L}^{-1}$ & $\mathbf{L}$ & & & AE 1 \\
\hline $\begin{array}{l}\text { Boom-lype } \\
\text { Boom-lype (edjusted)y } \\
\text { Senthmgt Milly-Wabblet } \\
\text { Ein Dor } 899-328 \\
\text { Ein Dor } 861-120\end{array}$ & $\begin{array}{l}76 \pm 0.17 \\
18131 \\
940 \pm 114 \\
766 \pm 54 \\
734 \pm 76\end{array}$ & $\begin{array}{r}261165 \\
261165 \\
137.9 \\
122.4 \\
97.3\end{array}$ & $\begin{array}{c}13 \% \times 10^{\circ} \\
\left(212 \times 10^{4}\right) \\
179600 \\
97800 \\
67700\end{array}$ & $\begin{array}{c}1.92 \times 10^{4} \\
\left(25 \times 10^{4}\right) \\
128.000 \\
9320 \\
6770\end{array}$ & $\begin{array}{c}7 \\
(739) \\
934 \\
761 \\
734\end{array}$ \\
\hline
\end{tabular}

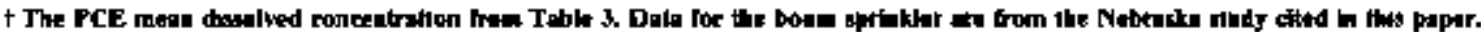

+ Colution A $\times$ Collons B.

Colnen $\mathrm{C} \times$ \% rempis.

1 Column DiColuma B.

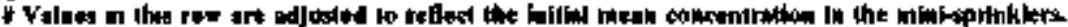

than did the mun-sprunklers; however, the mass of TCE or PCE that the boom-type spotrkler removed per liter of influent water (Column $E$ in Tables 7 and 8 ) was within the range of that removed by the min-sprinklers Both systems (mut-sprunklers and boom-type) remove comparable levels of TCE and PCE per liter per hour.

The mint-spunkler systems have merit for use un the cleanup of TCE and PCE un contamunated ground wa. ter Allhough the rass of TCE and PCE removed per liter per hour was comparable with that removed by a large agnicultural boom-type sprinkler, the min-spnnklers would have to run approxunately 1600 to 3000 times longer to strip the same total mass as the boontype sprinkler removed in $1 \mathrm{~h}$ This equates to 66 to $125 \mathrm{~d}$ for each hour that the boom-rype sprukler is operated This duference, however, does not exclude the use of mini-spruklers for remed atuon purposes $l n$ steep areas in whych the boom-lype sprinklers cannot be used or in areas in which the removal of large ground water volumes (consider that the boom-1ype spunkler In the Nebraska study removed $4353 \mathrm{~L} \mathrm{~min}^{-1}$ or 1150 gal min ${ }^{-1}$ ) เs prohibuted, the mun-sprinklers could be installed in sufficient numbers to regulate the dauly volume of ground water that il removes to an "acceptable" level whle at the same tome sinp TCE and PCE from the water The acceptable Jevel would depend on the dissolved concentralions of TCE and PCE in the ground water, the suze of the contaninated plume, the timeframe for the remedjation process, and other site cond1fions such as soil saturation and concern for off-stte drift and leachng of other contammanis in the sold Agricutture is under tncreasing pressure from the general public and govemment agencies to regulale the volume of ground water that its large boom-type imgatIon systems use In some areas, ground water has been removed at a rate that approaches or exceeds the te. charge rate Thus process has resulted in the imposing of striel or no-water usage by both nonagricultutal consumers and farmers Smaller munt-sprunklers such as the ones used in this study may provide a means to help remedlate some VOCs from ground water whule at the same tume proteclung the ground water volume agausi depletion beyond ats recharge rate

\section{CONCLUSIONS}

This study snvestigated the potential for muni-spnnkler systems to sIrIP TCE and PCE from ground water
Each misi-spnokler system reduced dissolved concentrations of TCE by 99 to $100 \%$ and PCE by 96 to $100 \%$ in water that contatned 466 to $1675 \mu \mathrm{g} \mathrm{L}-1$ TCE and 206 to $940 \mu \mathrm{g} \mathrm{L^{-1 }}$ PCE This percent reduction was based on the highest Jevel of TCE or PCE detected in any one sample for each test system and was adjusted for the percent loss during a l-h sample aceumulation period Adjusting for this percent loss, the highest dissolved concentration of TCE or PCE detected in any collection vessel was 132 and $236 \mathrm{\mu g}^{-1}$. respectuvely

Muru-sprnklers offer the advantages of casy sctup in senes that could be used on practically any terrain. operation over a long period of time that would not threaten aquifer depletion, use in small or confined aqufers in which the capacity is too low to support large intigation or purgeng systems, and use in forests in which the small, low-mpact droplets of the mini-sprinklers would not damage bark In Jorests, trees could help manage (via evapotranspiration) excess waste water ln loblolly and other pine forests that are commoth in the southeastem USA, the mini-sprinkiers could be operated nearly year-tound

\section{ACKNOWLEDGMENTS}

This work was fonded by the Department of Energy Si vannah River Site. through Westinghouse Savannah Kiver Company. Environmental Restoralion Division, and the USDA-Fortst Service, under Inleragency Agreement no DE. Al09.76SR0O056 The authors wish to thank Mr Rafael Rivera Mendez for his technocal laboratory assistante and Mr Mark Lurey (ML. Irrigalion, Laurens, 5C) for his assistance in designing and assembling the mini-sprinkler systems WSRC Nonexclusive Copynght Agreement PUB-03-002

\section{REFERENCES}

Adarts, J A, and K R Reddy 1999 Laboratory siudy of alr sparging of TCE-Conlanmirsted gaturated soils and groundwaler Ground Water Mont Rem 19 IB2-190

Cash, D 1998 Asstssing and addressing coss seale envuronmenia] risks Informalon and decsens systerins for the management of the High Plains Aquiler ENRP Dacusson Paper E QR-1] A vallable online

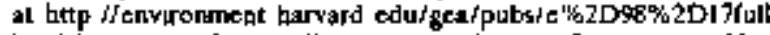
him (verified 21 Jan 2uoj) Kennedy scbool of Governmenl Har vard Unuw, Cambndge, MA

Chang. Y C. B C Oreke, M Hatsu, and K Takamizawa 2001 In viteo dehalogenatron of Itetrachlorocthylene (PCE) by teld free ex teacts of Clostridiom bifermenant DPH.1 Bioresour Technol 78 141-147? 
Cheng. $S$, and $S$ Wu 200] Ferasibility of using metsls to remediate waler contanugg TCE Chemosphere 43 l023-1028

Dretz AC and J S Scbnoor 2001 Adrances in phytoremedialion Environ Health Perspect $109163-168$

Gates, D D, and R L Stegrist I9S5 In-situ chemeal oxidation of truchlortel hylent using hỵdtogen peroxide I Environ Eng (Res. (OOH, VA) 121 639-644

Leahy, $J G$, and $G 5$ Shreve 2000 The effect of organe carbon on the sequenisal reductive dehalogenatiog of teirachloroethylene in landfoll leachates Water Res 34 2390-2396

McCarly, P L Z ZOOO Novel brologeral jemoval of hazardous themicals at itate ke vels Water $S_{C l}$ Teechnol $\$ 2$ 49-60

McCulloch $A$, and PM Midgley 1996 The ptoduction and ghobal distribulion of emissions of trrchloroethente, te1 rachloroethene, and dichloromethane over the penod lygs-IM92 A100es Environ $30601-6068$

Microsofl Corperalion 2000 Excel Microsot Corp. Redmond, WA

Minopoulos, P G , G D Sayles, M T Sujden, J Shah, and D F Bjehop to00 Vapor phase treatment or PCE in a sonl column by lab scale anaerobit biovening Waler Res 34 3231-3237

Newman. L A, SE Strand, N Choe, J Duffy, G Ekuan, M Ruszaj. B B Shurcleff, J Wilmolh, P Heilman, and M P Gordon 1997 Uptake and brotransformanion of trichloroethyke ne by hytrid poplave Environ Sci Techpol 31 Inos2-106]

Rabideas A.J.JM Blayden, and C Ganguly 1990 Field perfor. mance of aIT-groundwatering system tor temoving TCE Irom groundwater Environ Sa Techiol 33 1\$7-162

Reddy K R, and J A Adems 2006 Efrect of groundwaler tlow on remedialion of dissolved.phase VOC contamunation using alr goundwatertng I Hazard Moler 72 147-165

Rıchardson, T L, and E Sathe Demessie 1968 Sprinkler Imgainon Lor the remoyal of VOCs trom groutudyater Enyaron Technol $191049-1054$

Ryą K W, DM Dwighi, and DA. Hlousek 2000 Recirculaing wells Groundwater remediation and protection of surface water resources J An Water Regour Assoc 36 191-201

SAS Insiltute 2000 SAS Ver5ı $B$ I SAS InsI, Cary, NC

Schrarr M C Truax, G Farquhar, E Hood, T Gonullu and B Stickney. I 948 Laboralory and controlled treld experiments using polassium permanganate to remediate trichloroethylene and per chlorpethylene DNAPLs in porous media I Contarp Hydrol $29205-224$

Schroth MH, M Ossolrom, TW Whetsmd, and J D Islok 2001 In silu oxidainon of trichloroeshene by permangatale Effects on porous medium hydraulic properiıeg I Coptam Hydrol $5079-98$

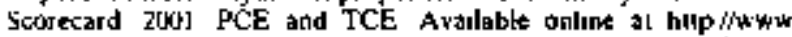
scofecard or g/che asical profileg/hazard anducalors tel?cdr Stbbsiance rd $=127 \% 2 \mathrm{~d} 18 \% 2 \mathrm{d4}$ (for PCE, verifed $29 \mathrm{Jan} 2003$ ) and hilp //wrw scoresand orgicherncel profiles/hazard inderalors

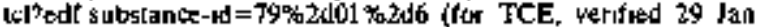
2003) Envisonmenial Defense, New York

Suet $Y$ and F W Schwartz 2000 Phasc-transfer catslysss spptred to the oxidation of nonaqueous phase trichloroeihylene by potassium permanganate $J$ Contan Hydrol $\mathbf{4 4}$ 185-201

United Stales Geological Survey 2000 Invegldgation groundwaler

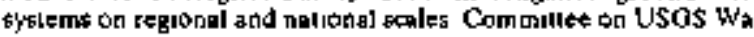
ter Resources Research Nall Academy Ptess, Washungton, DC

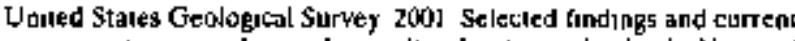
nerspectives on urban and aggieul rural water qualuly by the Natuons. Wale-Qualıy Assessment Program Avallable on line al littp:

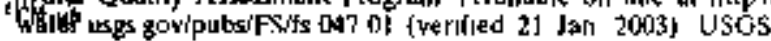
Reston, VA

USEFA 1985 Defisalion of the procedure for the deiermination of the method detection liemil Code of Federal Regulanions 40 CrR Ch I 7.1 BS edicon) Parl 136, Appendix B Nall Archdvęs anb Records Admiousitation, Washington, DC

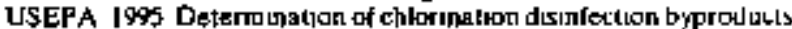
chkonnaled solvents, and halogethated pest litdetherbalides jo drink Ing water by liquid-inquid extraction and gas chromalograpty with electronsapture delection Revison 10 ft LJ S Envtrommenla Protertoon Agency methods and gurdance for analysits of warter Nall Exposure Res Lab. Cincinnat|, OH

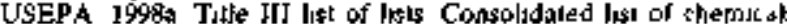
subjor to the Emergency Plapning and Communily Right to Know Act (EPCRA) and Sectwon l12(t) or ihe Clean A.r Act as amended EPA 550 B 98 or 7 Avadlable online at hitp iposetrulc epa gov oswericepporeb nsficonlenticheriucals htm\%openDocument (verı Eved 30 Jan 2003) USEPA Office of Solid Wastes and Emergerkey Response, Washington, bC

USEPA 1998b Remedialion cases gtudes Groundwater pump and treal (cblortnated solvents) Vol O EPA.S47 R.9g ol 3 USEPA Washington, DC:

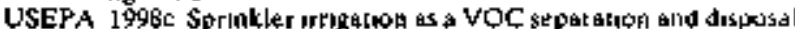
melhod Innovalive Techiol Evaluation Rep EPA/S4lwR ob 502 USEPA, WashingIon, DC

USEPA 2000 The HPV volunlary challenge chemical list A Hallable

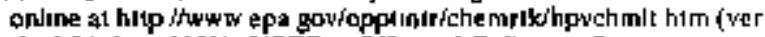
ified 21 Jan 2009) UȘEPA Offices of Pollution Prevention alto Toxics, Washıngton, DKC

USEPA 2001 TRI 1999 dala rolesse Appendix A Chemust spetalic TRI release and wasse management data 1989 1995. J998 and

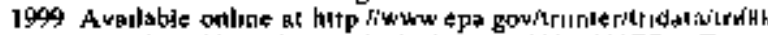

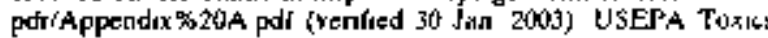
Release Inventory. Washington, DC

Van Eckert. MHA. TI Schroder, A van Rhee A IM Sidms $G$ Scbra, and IA Fjeld 2001 Constitulive dectionnálion o1 chlorinated ethenes by a methanol degrading me th anogenic consor cum Budresous Tecturiol $77163-170$

Vroblesky, D A 2000 Simple, toexpensite diffusion samplers lur mosiloring $V Q C 5$ in groundjwater $p$ 349-\$56 in G E Wickramd nayake el al (ed) Proc. The 2nd Int Conf on Remediation al Chlorinaled and Recakelrara Compounds Monlersy CA t? 27 May 2000 Batlelle Press, Columbus. OH

Vroblesky. D A 2001 a User's guide for polyeshylente based passure diffuswn bag sainpleis wo oblain volanle organic coimpound concetn Iratmons in wells, Pari 1 Deployme hi, recovery daya interpretation and qualsy conlrol and assurance Waster Reseur lawestigasions Rep 01 d0Ga US Geol Survey. Resion. VA

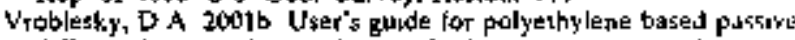

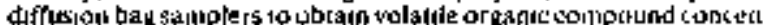
Italions in wells. Part 2 Field lests Water Resour levestigations Rep 01-A061 US Geol Surey. Resion, VA

Vtobtesty, D A, and T R Campbeil 2loht Equdibralion limes s1abil ty, and compound selochiyity of diffursion samplers for collection of ground waler VOC concentirations Ady Enyiron Res $5 \mathrm{l}-1$ ? 